\title{
2023 Eğitim Vizyonunun Akademik Çalışmalara Yansımaları: Bibliyometrik Bir Analiz
}

\author{
DOI: 10.26466/opus.918815
}

Öz

\author{
Ciğgdem Ayanoğlu ${ }^{*}$ - Tanju Demir ** - Duygu Gür Erdoğan *** \\ * Dr. Öğr., Hacettepe Üniversitesi, Ankara/Türkiye \\ E-Posta: cigdemayanoglu@hotmail.com \\ ORCID: $\underline{0000-0002-2117-0872}$ \\ ** Yl. Öğr., Sakarya Üniversitesi, Sakarya/Türkiye \\ E-Posta: demir.tanju@gmail.com \\ ORCID: $0000-0003-3658-9286$ \\ *** Dr. Öğr. Üyesi, Sakarya Üniversitesi, Sakarya/Türkiye \\ E-Posta: dgur@sakarya.edu.tr \\ ORCID: $\underline{0000-0002-2802-0201}$
}

Türkiye'de eğitim sistemi için benimsenen temel vizyonun, bu vizyonun felsefi temellerinin ve 2023 yllna kadar gerçekleştirilmesi planlanan hedeflerin yer aldığ 2023 Ĕ̆itim Vizyon Belgesi yayımlandığı tarihten itibaren bilimsel araştırmalara konu olmuştur. Bu araştırmada, 2023 Eğitim Vizyon Belgesi ile iloili yayımlanan akademik çalışmalarm incelenmesi amaçlanmıştır. Araştırma betimsel araştırma modelinde desenlenmiş olup doküman incelemesi yöntemi ile gerçekleştirilen nitel bir araştırmadır. Araştırmaya DergiPark ve ResearchGate veri tabanından 02.01.2021 tarihinde erişilen 36 makale dahil edilmiştir. Erişilen makalelerin yaym yıll, yayın dili, yayımlanan dergi, yazar sayısı, anahtar kelime ă̆ı, atıf sayısı, en çok birlikte atıf yapılan yazar ve yayın araştırma yöntemi, örneklemi, veri toplama teknikleri ve konu yönelimi parametreleri açısından bibliyometrik analizi gerçekleştirilmiştir. Araştırma sonucunda, analiz edilen makalelerin farklı birçok dergide yayımlanarak alanyazına katkı sağladığı, çoğunlukla iki ve daha fazla yazarl olduğu, daha çok kavramsal araştırma yaklaşımı benimsenerek, doküman incelemesi ve görüşme tekniği kullanılarak nitel yöntem ile gerçekleştirildiği tespit edilmiştir. Makalelerde Vizyon Belgesinin, "genel değerlendirmesi ve uygulanabilirliği", "mesleki eğitim", "eğitim yönetimilyöneticiliği" ve "tasarm ve beceri atölyeleri" daha çok olmak üzere farkl konu alanlar açısından ele alındığı ancak belgede yer alan birç̧ok alanın henüz akademik çalışmalara konu olmadığı belirlenmiştir. Çalı̧̧a, 2023 Eğitim Vizyon Belgesi ile ilgili yapılan çalı̧malarm yönünü ve eğilimlerini göstermesi açısından araştırmacilara yol gösterebilir ve bundan sonra yapılacak çalışmalarda yararlanılacak bir kaynak olabilir.

Anahtar Kelimeler: Millî Eğitim Bakanlı̆̆ı, 2023 Eğitim Vizyonu, Bibliyometrik analiz. 


\title{
Reflections of the 2023 Educational Vision on Academic Studies: A Bibliometric Analysis
}

\begin{abstract}
The primary vision adopted for the educational system in Turkey, the philosophical basis of the realization of the vision until 2023 and where the planned target 2023 Education Vision Document has been the subject of scientific research from the date of publication. In this research, it is aimed to examine the academic studies published on the 2023 Education Vision Document. The research is designed in a descriptive research model and is a qualitative research conducted with document analysis method. 36 articles accessed from DergiPark and ResearchGate database on 02.01.2021 were included in the study. The bibliometric analysis of the accessed articles was performed in terms of publication year, publication language, published journal, number of authors, keyword network, number of citations, most co-cited author and publication, research method, sample, data collection techniques and subject orientation parameters. As a result of the research, it was determined that the analyzed articles contributed to the literature by being published in many different journals, they mostly had two or more authors, and they were carried out with a qualitative method, using a more conceptual research approach, document analysis and interview technique. In the articles, the Vision Document is discussed in terms of different subject areas, such as "general evaluation and applicability", "vocational education", "education management " and "design and skill workshops", but it has been determined that many areas in the document are not yet subject to academic studies. The study can guide researchers in terms of showing the direction and tendencies of the studies regarding the 2023 Education Vision Document and can be a resource to be used in future studies.
\end{abstract}

Keywords: Outbreak, Individual Preparation, Health Belief Model, Teachers, School Administrators 


\section{Giriş}

Değişen dünyada bireylerin, toplumların ve örgütlerin değişimden kaçınması mümkün görünmemektedir. Değişim kaçınılmaz bir şekilde gelişimi, gelişim ise başarıyı bahaneye tercih ederek daima ileri bakmayı ve görmeyi gerekli kılmaktadır. Görmek anlamına gelen Latince "vide" kelimesi İngilizce "vision", Türkçe "vizyon" kelimesinin karşıllğıdır (Alkoç, 2010). Türk Dil Kurumu sözlügünde "görünüm", "ülkü", "sağgörü" ve "ileri görüş" anlamlarıyla karşımıza çıkan vizyon kelimesi geleceğin bir görünümüdür. Ancak bu görünüm, gelecekte arzu edilen bir durumun ifadesidir (Dinçer, 1998). T. C. Millî Eğitim Bakanlığınca hazırlanan 2023 Eğitim Vizyon Belgesi, eğitim sisteminin geleceğe dair arzu edilen bir görünümünü sunmaktadır. Belge, "Mutlu Çocuklar Güçlü Türkiye” vurgusuyla 2018 yılında uygulamaya konulmuştur.

Türkiye'de eğitim sistemi için benimsenen temel vizyonun, bu vizyonun felsefi temellerinin ve Millî Eğitim Bakanlığının 2023 yılına kadar gerçekleştirmeyi planladığı hedeflerin yer aldığı 2023 Eğitim Vizyon Belgesi 23 Ekim 2018 tarihinde yayımlanmıştır. Belgenin eğitimde var olan paradigmatik dönüşüm ihtiyacı sebebiyle gündeme geldiği ve temel amacının çağdaş beceri ve yeterliklere sahip, insanlığın yararına çalışan, bilime ve kültüre değer veren, ahlaklı bireyler yetiştirmek olduğu belirtilmiştir. Orta vadede kalite konusunda bir atılım ve eğitimde sürdürülebilir bir yol haritası sunma ana hedefiyle hazırlanan belgede yer alan hedeflerin 2018-2019 eğitim öğretim yılında tasarım ve öncü pilotlamalarının uygulanması; 2019-2020 eğitim öğretim yılında ülke genelinde pilotlama ve uygulamaların gerçekleştirilmesi; 2020-2021 eğitim öğretim yılında ise tüm hedeflerin hayata geçirilmesiyle üç yılda tamamlanması planlanmıştır (T. C. Millı̀ Eğitim Bakanlığ1 [MEB], 2018).

2023 Eğitim Vizyon Belgesi eğitim felsefesi, temel politika, içerik ve uygulama, okul gelişim modeli bölümleri ile başlamakta; ardından veriye dayalı bir yönetim sisteminin oluşturulması, ölçme değerlendirme, insan kaynaklarının geliştirilmesi, okulların finansmanı, teftiş sistemi gibi eğitimin yönetimi ile ilgili bölümler ve rehberlik ve psikolojik danışmanlık hizmetleri, özel eğitim, özel yetenek, yabancı dil eğitimi, öğrenme süreçlerinde dijital içerik ve beceri destekli dönüşüm bölümleri bulunmaktadır. Son bölümde ise okul öncesi, temel eğitim, ortaöğretim, Fen ve Sosyal Bilimler Liseleri, 
İmam Hatip Okulları ve Liseleri, özel eğitim ve hayat boyu öğrenmeye yönelik hedeflere yer verilmiştir (MEB, 2018). Taş (2018)'a göre 2023 Eğitim Vizyon Belgesi, gerçekleştirilmesi planlanan değişim ile ilgili alanların planlanması, değişime dair bir yol haritası çizilmesi ve çağın ihtiyaç duyduğu ideal insan ve ideal toplum tasvirinin belirlenmiş olması sebebiyle eğitim sistemine yol gösteren bir belgedir.

Küreselleşme ile sınırların yok olması, bilim ve teknolojideki gelişmeler toplumların yaşamlarını etkilemekte; sosyal, siyasal ve ekonomik alanlarda çok çeşitli değişimler yaşanmaktadır. Bu gelişmelere bağlı olarak eğitim sistemlerinde yeni yapılanmalara ihtiyaç duyulmaktadır (Çağlayan ve K1ratlı, 2017). Türkiye'de son yıllarda eğitim sisteminde uzun zamandır veriye dayalı, katılımcı ve uzun vadeli politikalara ihtiyaç duyulmakta (Eğitim Reformu Girişimi, 2018), toplumun beklentilerine ve çağın gereklerine cevap verilememekte (Türk Eğitim-Sen, 2018), sistemsizlik veya düzensizlik tartışmaları üzerinden eleştiriler yöneltilmekte (Baltacı ve Coşkun, 2019) ve özellikle son yıllarda eğitimin sınıf geçmeye, sınavları kazanmaya ve iş bulmaya odaklandığı görülmektedir (MEB, 2018). Ayrıca eğitimde uygulanan tutarsız politikalar sebebiyle ülkelerin eğitim performanslarını değerlendiren PISA ve TIMMS gibi sınavlarda Türkiye'nin aşağı yöndeki ivmesi eğitimde güçlü bir dönüşümü zorunlu kılmaktadır (Baltacı ve Coşkun, 2019). Bu nedenle 2023 Eğitim Vizyonu, eğitim sisteminde yıllardır beklenen sorunların çözümü için umut verici bir adım olarak görülmektedir (Emin, 2018; Ertürk, 2020; Minaz ve Dikmen, 2019; Dayığlu Öcal ve İşcan, 2020; Sözer, 2019; Taş, 2018). Eğitim sistemi içerisinde yer alan tüm paydaşları bir şekilde heyecanlandıran belge (Sözer, 2019), aynı zamanda Türk Eğitim Sistemi politikasının şekillenmesinde önemli bir rol oynayacaktır (Dayığlu Öcal ve İşcan, 2020). Vizyon belgesi eğitim sistemindeki sorunlara çözüm getireceği umudu (Emin, 2018; Ertürk, 2020; Minaz ve Dikmen, 2019; Öcal ve İşcan, 2020; Sözer, 2019; Taş, 2018), yenilik ve gelişmelere açık bir sisteme vurgu yapması (MEB, 2018), Milli Eğitim Bakanlığının daha önceki politika belgelerinden farklı olarak alınan kararların bilimsel analizlere dayandırılarak uygulamaya konulmasinı hedeflemesi (Yatmaz, 2019), toplumun ve eğitim paydaşlarının yakın ilgi göstermesi, bununla birlikte umulanı karşılamadığına ilişkin eleştirileri beraberinde getirmesi, ilk defa bir eğitim politika belgesinin toplum huzurunda bu denli gündeme gelmiş olması (Hamarat ve Alkan, 2018) sebepleriyle birçok araştırmacının ilgisini çekmiştir. Bu 
nedenle yayımlandığı 23 Ekim 2018 tarihinden itibaren 2023 Eğitim Vizyon Belgesinin çeşitli yönleri ile incelendiği çalışmalara rastlamak mümkündür. Yapılan bu akademik çalışmalar 2023 Eğitim Vizyon Belgesinin farklı açılardan incelenmesine olanak sağlamıştır. Nitekim belgenin çeşitli paydaşlarca eleştirilmesi, değişime açık kalarak tartışlması, etkili iletişim çalışmalarının yürütülmesi belgenin paydaşlarca sahiplenilmesi ve benimsenmesi açısından önemlidir (Eğitim Reformu Girişimi, 2018). Ayrıca yapılan akademik çalışmalar, belgenin uygulanmasında gerçekleşmesi muhtemel sorunların belirlenmesi ve bu yönde yapılan öneriler ile yapılabilecek iyileştirme çalışmaları açısından da önemlidir (Sözer, 2019). Çalışmalarda, uygulama sürecinde atılacak somut adımların Eğitim Vizyon Belgesindeki hedeflere ulaşmada belirleyici bir faktör olacağı belirtilmiş ve bu konuda somut ve gerçekçi birçok politika önerileri sunulmuştur (Arkan ve Öztürk, 2018; Can, 2019; Hamarat ve Arkan, 2018; Doğan, 2019; Doğan vd., 2019; Tarhan, 2019).

2023 Eğitim Vizyonu için öngörülen uygulama süresi 3 yıllık bir süreyi kapsamaktadır. Oysa özünde "vizyon" uzun vadeli bir gelecek planlamasidır. İlk bakışta böyle bir çelişki görünse de aslında 2023 Eğitim Vizyon Belgesi, amacını sürdürülebilir bir yol haritası olarak ifade ederek uzun bir süreyi etkisi altına alacak köklü bir değişime vurgu yapmaktadır. Bu nedenle vizyon belgesinin uzun vadeli bir gelecek hedefi için bir başlangiç olduğu ve geliştirilmeye, revizyona açık olduğu düşünülebilir. Bu noktada yapılan akademik çalışmaların bu gelişim ve revizyona katkısının oldukça fazla olabileceği söylenebilir. Taş (2018)'a göre eğitim ile ilgili sorunların güncel polemiklerden ve ideolojik tartışmalardan uzak tutulması, akademik bir bakış açısıyla tartışılarak çözümlenmesi etkili bir sistemin oluşmasını sağlayacaktır.

2018 yılından itibaren günümüze değin 2023 Eğitim Vizyon Belgesine yönelik yapılan bilimsel yayınların artması araştırmalarda incelenen noktaların ve ortaya çıkan sonuçların özetlenmesi bütünsel bir bakış açısı oluşturulmasına olanak sağlaması açısından önemlidir. Bu amaçla bu çalışmada 2018 yılında yayımlanan 2023 Eğitim Vizyon Belgesi ile ilgili bugüne kadar yapılan ve araştırma kapsamında erişilen 36 yayının çeşitli parametreler açısından bibliyometrik analizi gerçekleştirilmiştir. Yapılan bu çalışma ile Eğitim Vizyon Belgesi ile ilgili üretilen bilimsel bilginin miktarı ve kapsamı hakkında bilgi edinilmesi, konunun hangi noktalarına odaklanıldığı ve 
hangi noktalarının daha az ele alındığının belirlenmesiyle veriye dayalı objektif bir genel değerlendirme yapılması sağlanmıştır. Ayrıca 2023 Eğitim Vizyon Belgesi ile ilgili araştırmaların gelişiminin de gözlenmesi mümkün olmuştur. Bu değerlendirmelerin uygulamalar, iyileştirmeler veya yeni düzenlemeler ile ilgili Millî Eğitim Bakanlığına veri sunacağı, günümüze dek yapılan araştırmaların profilinin ortaya çıkarılması ile henüz yeterince üzerinde durulmamış noktalar ile ilgili alana yön veren çalışmaların yapılması yönünde eğitim bilimcilere yol göstereceği, alana 1şık tutacağı ve katkı sağlayacağı umulmaktadır. Bu doğrultuda 2023 Eğitim Vizyon Belgesini konu alan çalışmaların, bilimsel yayınların bütünsel olarak değerlendirilmesinde güçlü ve derin bir analiz yöntemi olan bibliyometrik analiz yöntemi tercih edilmiştir.

Bibliyometrik analiz, bilimsel araştırmaların istatistiksel olarak analiz edilmesidir. Bilimsel araştırmaların yazar ismi, anahtar kelime, kullanılan yöntem, atıf gibi birçok özelik açısından analiz edilmesine olanak sağlayan bibliyometrik analiz ile elde edilen veriler (Al ve Coştur, 2007) alanın yapısı ve dinamikleri hakkında bilgi verir. Özellikle sosyal bilimler alanında, bilimsel sonuçların bütünsel olarak değerlendirilmesinde güçlü ve derin bir analiz yöntemi olan bibliyometrik analiz (Liu vd., 2014'ten akt. Tekin, 2019) alandaki eğilimlerin tespit edilmesini sağlar (Köseoğlu, 2016). Geçmiş araştırma eğilimlerinin ortaya konulması ile gelecek eğilimler tahmin edilir ve belirlenir (Zhao vd., 2018). Ayrıca bibliyometrik araştırmalar sağladığı bilgi birikimi ile sistematik çalışmayı kolaylaştırır (Sünnetçioğlu vd., 2017).

Araştırmada 2018 yılında yayımlanan 2023 Eğitim Vizyon Belgesi ile ilgili bugüne kadar yapılan ve erişilen 36 makalenin çeşitli parametreler açısından bibliyometrik analizi gerçekleştirilmiştir. Çalışmada yayın türü olarak makalenin seçilmesinin sebebi makalenin akademik üretim açısından değerli olması ve araştırmacıların akademik etkinliğini ve bilimsel üretkenliğini ortaya koymasında güçlü bir yazın olmasıdır (Bozdoğan, 2020; Chao vd., 2007; Karagöz ve Koç Ardıç, 2019; Karagöz ve Şeref, 2019a; Koley ve Sen, 2016). Çalışmanın amacı doğrultusunda 2023 Eğitim Vizyonu Belgesi ile ilgili yayınların; (a) yıllara göre, (b) yayın diline göre, (c) yayımlandığı dergilere göre, (ç) yazar sayılarına göre, (d) anahtar kelimelerine göre, (e) atıf sayısına göre, (f) en çok birlikte atıf yapılan kaynak ve kaynak sayısına göre, (g) araştırma yöntemlerine göre, (h) örneklem grubuna göre, (1) veri topla- 
ma tekniklerine göre, (i) konu yönelimine göre dağılımı nasıldır? sorularına cevap aranmıştır.

\section{Yöntem}

\section{Araştırma Modeli}

Araştırma betimsel araştırma modelinde desenlenmiş olup doküman incelemesi yöntemine dayalı olarak gerçekleştirilen nitel bir araştırmadır. Hedeflenen olgu ya da olaylar ile ilgili yazılı bilgi içeren kaynakların derinlemesine incelenerek analiz edilmesine olanak sağlayan doküman incelemesi yöntemi (Yıldırım ve Şimşek, 2018), çeşitli araştırmacılar tarafından toplanan veriler arasındaki ilişkilerin çözümlenmesiyle ilk anda anlaşılmayan karmaşık sorunlara çözüm bulunmasını sağlar (Karasar, 2017). Eğitim bilimleri konularının içinde bulunduğu mevcut yer ve zamanda ele alınmasını gerektirmesi, genelleme ve tekrar edilmesinin güçlüğü nedenleriyle doküman incelemesi yöntemi eğitim araştırmalarında başvurulan bir araştırma yöntemidir. Bu yöntemle önceden fark edilemeyen noktaların ortaya çıkarılarak sorunların çözümlenmesi, daha sağlıklı değerlendirmeler yapılarak geleceğe yönelik sağlam planlar yapılması, anlamlı ve gerçekçi veriler elde edilmesi mümkündür (Özkan, 2019). Bu nedenle çalışmada 2023 Eğitim Vizyon Belgesi ile ilgili 23 Ekim 2018 tarihinden itibaren yayımlanan akademik çalışmalar bibliyometrik göstergeler açısından incelenmiştir.

\section{Verilerin Toplanması}

Araştırmada kullanılan veriler, TÜBİTAK ULAKBİM çatısı altında Türkiye'de yayımlanan akademik hakemli dergileri elektronik ortamda sunan ve editörlük hizmeti veren DergiPark ve ResearchGate veri tabanlarından 02.01.2021 tarihinde erişilen makalelerden elde edilmiştir. Veri tabanlarından "2023 Eğitim Vizyonu" "Eğitim 2023 Vizyonu" "2023 Eğitim Vizyon" "2023 Education Vision" kelime grupları ile başlık, anahtar kelimeler ve öz alanlarında arama gerçekleştirilmiştir. Arama sonucunda erişilen 43 yayından 5'inin konferans bildirisi olduğu, 2'sinin ise öz k1smında "2023 Eğitim Vizyon Belgesi" ve "Eğitim 2023 Vizyonu" kelime grupları yer almasına rağmen 2023 Eğitim Vizyon Belgesi ile ilgili bir çalışma olmadığı tespit edilmiş ve araştırmaya dâhil edilmemiştir. 2023 Eğitim Vizyon Belgesi ile 
ilgili erişilen diğer 36 yayın (makale) araştırma kapsamına alınmıştır. Araştırma kapsamına alınan yayınlar Tablo 1'de sunulmuştur.

Tablo 1. Araştırma Kapsamında İncelenen Yayınlar

\begin{tabular}{|c|c|}
\hline Makale Adı & Yil \\
\hline $\begin{array}{l}\text { Sosyal bilgiler öğretmenlerinin } 2023 \text { Eğitim Vizyonuna yönelik görüşlerinin incelenmesi } \\
\text { (Köç ve Ünal, 2018) }\end{array}$ & 2018 \\
\hline 2023 Eğitim Vizyonunda erken çocukluk eğitimi (Arkan ve Öztürk, 2018) & 2018 \\
\hline 2023 Eğitim Vizyonu ve mesleki ve teknik eğitimde yeni hedefler (Özer, 2018) & 2018 \\
\hline Eğitim Bilişim Ağı (EBA) ve 2023 Eğitim Vizyonu (Arkan ve Kaya, 2018) & 2018 \\
\hline 2023 Eğitim Vizyon Belgesi'nde gelecek becerileri (Hamarat ve Arkan, 2018) & 2018 \\
\hline Yönetim bilimi perspektifinden MEB Vizyon Belgesi (Arkan ve Karaboğa, 2018) & 2018 \\
\hline $\begin{array}{l}\text { MEB } 2023 \text { Eğitim Vizyonu çerçevesince Türkiye'de girişimcilik eğitiminin geleceğine } \\
\text { yönelik bir değerlendirme (Tarhan, 2019) }\end{array}$ & 2019 \\
\hline $\begin{array}{l}\text { İ̉nilizce öğretmenlerinin erken yaşta İngilizce öğretimine ilişkin yeterlilikleri-Kütahya ili } \\
\text { örneği (Şad ve Sarı, 2019) }\end{array}$ & 2019 \\
\hline $\begin{array}{l}2018 \text { ortaöğretim matematik programının revize Bloom taksonomisine ve programın } \\
\text { öğelerine göre incelenmesi (Çil vd., 2019) }\end{array}$ & 2019 \\
\hline $\begin{array}{l}2023 \text { Eğitim Vizyonu Belgesine ilişkin okul yöneticileri ve öğretmen görüşleri (Doğan, } \\
\text { 2019) }\end{array}$ & 2019 \\
\hline 2023 Eğitim Vizyonuna ilişkin öğretmen görüşleri (Duran ve Kurt, 2019) & 2019 \\
\hline $\begin{array}{l}\text { Okul müdürlerinin } 2023 \text { Eğitim Vizyon Belgesinde yer alan yöneticilerin mesleki gelişimle- } \\
\text { rine iliş̧in düzenlemelere yönelik görüşlerinin incelenmesi (Akyıldız vd., 2019a) }\end{array}$ & 2019 \\
\hline $\begin{array}{l}\text { Ortaöğretim özel program ve proje uygulayan eğitim kurumlarının arka planı ve proje } \\
\text { okul uygulamaları (Cırıt ve Günday, 2019) }\end{array}$ & 2019 \\
\hline 2023 Eğitim Vizyon Belgesi, tekillik ve transhümanizm (Köksal, 2019) & 2019 \\
\hline $\begin{array}{l}2023 \text { Eğitim Vizyon Belgesinde yer alan öğretmenlerin mesleki gelişimleri ile ilgili politika- } \\
\text { ların öğretmen görüşlerine göre değerlendirilmesi (Akyıldız vd., 2019b) }\end{array}$ & 2019 \\
\hline 21. Yüzyıl becerileri odağında Türkiye'nin eğitim politikaları (Hamarat, 2019). & 2019 \\
\hline $\begin{array}{l}\text { The role of community-based early childhood programmes in children learning: The } \\
\text { concept of funds of knowledge (Gelir, 2019) }\end{array}$ & 2019 \\
\hline 2023 Eğitim Vizyon Belgesine ilişkin öğretmen algısı (Baltacı ve Coşkun, 2019) & 2019 \\
\hline 2023 Eğitim Vizyonu: sorunlara çare mi? (Ertürk, 2020) & 2020 \\
\hline $\begin{array}{l}\text { Nurettin topçu ile Türk Eğitim Sistemini yeniden düşünmek (Örsdemir ve İhtiyaroğlu, } \\
\text { 2020) }\end{array}$ & 2020 \\
\hline Türkiye'de mesleki eğitimde paradigma değişimi (Özer, 2020a) & 2020 \\
\hline Okul müdürlerinin gözünden “Okul 2023” projesinin incelenmesi (Canbulat vd., 2020a) & 2020 \\
\hline $\begin{array}{l}\text { Öğretmen adaylarının perspektifinden Türk Eğitim Sisteminin sorunları ve olası çözüm } \\
\text { önerileri (Neyişci vd., 2020) }\end{array}$ & 2020 \\
\hline $\begin{array}{l}\text { İlkokul öğretmenlerinin tasarım beceri atölyelerinin etkililiğine ve uygulanabilirliğine } \\
\text { yönelik görüşleri (Gündüz, 2020) }\end{array}$ & 2020 \\
\hline $\begin{array}{l}\text { Milli eğitim bakanlığı } 2023 \text { Eğitim Vizyonu belgesi ve Dewey'in Türkiye maarifi hakkında } \\
\text { raporu: belge analizi (Dayığlu Öcal ve İşcan, 2020) }\end{array}$ & 2020 \\
\hline $\begin{array}{l}2023 \text { Eğitim Vizyon Belgesiyle oluşturulan drama ve eleştirel düşünce atölyelerinin Türkçe } \\
\text { dersi akademik başarısı üzerine etkisi (Kudak ve Akın, 2020) }\end{array}$ & 2020 \\
\hline 2023 Eğitim Vizyonu hakkında eğitim yöneticilerinin görüşleri (Solak ve Karataş, 2020) & 2020 \\
\hline
\end{tabular}


2023 vizyon Belgesi'nin karakter eğitimi bakımından değerlendirilmesi (Kıral ve Çilek,

2020)

Tasarım ve beceri atölyelerine yönelik uygulamalar-Almanya örneği (Öztürk, 2020)

Mesleki ve teknik ortaöğretimde paradigma değişimi için yeni bir adım: eğitim programla-

rının güncellenmesi (Canbal vd., 2020).

Okul 2023 projesinin öğretmenlerin gözünden incelenmesi: Bir durum çalışması (Canbulat

vd., 2020b)

The future of education in Turkey's 2023 Educational Vision Document: Views of academi-

cians in the faculty of education (Semerci vd., 2020)

Okul dışı öğrenme ortamlarının Türkçe dersi Ünitelendirilmiş yıllık planlarına yansımaları

(Bayburtlu, 2020)

Evaluation of digital content-supported transformation from teachers' perspectives within

\section{Verilerin Analizi}

Çalışma için erişilen yayınlar bibliyometrik analiz yöntemi kullanılarak analiz edilmiştir. Bibliyometrik analiz yazılı belgelerin çeşitli parametreler açısından analiz edilerek, bilimsel iletişime ilişkin çeşitli sonuçların elde edilmesine imkân sağlayan (Garfield, 1972' den akt. Al ve Coştur, 2007) sosyal bilimler alanındaki çalışmalarda sıklıkla kullanılan bir analiz yöntemidir. Bibliyometrik analiz ile elde edilen atıf ve literatür dağılımları çeşitli görselleştirme yöntemleri ile bilgilerin doğrudan sunulmasını sağlar (Tang vd., 2018). Bu bağlamda çalışmada incelenen yayınların (a) yayın yılı (b) yayın dili, (c) yayımlanan dergi, (ç) yazar sayısı, (d) anahtar kelime ağı, (e) atıf sayısı, (f) en çok birlikte atıf yapılan yazar ve yayın, (g) araştırma yöntemi, (h) örneklemi, (1) veri toplama teknikleri (i) konu yönelimi parametreleri açısından bibliyometrik analizi gerçekleştirilmiştir. Bibliyometrik veriler VOSviewer programı kullanılarak çözümlenmiştir. Elde edilen verilerin düzenlenmesinde ise Microsoft Office 365 ve VOSviewer programları kullanılmış, veriler tablo ve yoğunluk haritaları şeklinde sunulmuştur. VOSviewer programı bibliyometrik analiz çalışmalarında elde edilen verinin analizini, görselleştirilmesini ve metinler içerisindeki kavramlar ile kavramlar arasındaki ilişkilerin ortaya çıkarılmasında kullanılan bir programdır (Artsin, 2020). 


\section{Bulgular}

Bu bölümde araştırma verilerinin istatistiki değerlendirmeleri sonucu elde edilen bulgular tablo, ağ haritası veya yoğunlaştırılmış ağ haritaları halinde sunulmuştur.

\section{Makalelerin Yayımlandığı Yıllara İlişkin Bulgular}

Tablo 2'de araştırma kapsamında incelenen makalelerin yayımlandığı yıllara göre dağılımı görülmektedir. Buna göre 2020 yılında 17 (\%44), 2019 yılında 12 (\%33), 2018 yılında 6 (\%17) ve 2021 yılının ocak ayında 1 (\%3) makale yayımlanmıştır. Şekil 1'de makalelerin yayın yıllarına göre yoğunlaştırılmış ağ haritası yer almaktadır.

Tablo 2. Makalelerin Yayımlandığı Yıllara Göre Dağılımı (2018-2021)

\begin{tabular}{lll}
\hline Yayin Y1l & $\mathbf{f}(\mathbf{3 6})$ & $\mathbf{\%}$ \\
\hline 2018 & 6 & 17 \\
2019 & 12 & 33 \\
2020 & 17 & 44 \\
2021 & 1 & 3 \\
\hline
\end{tabular}

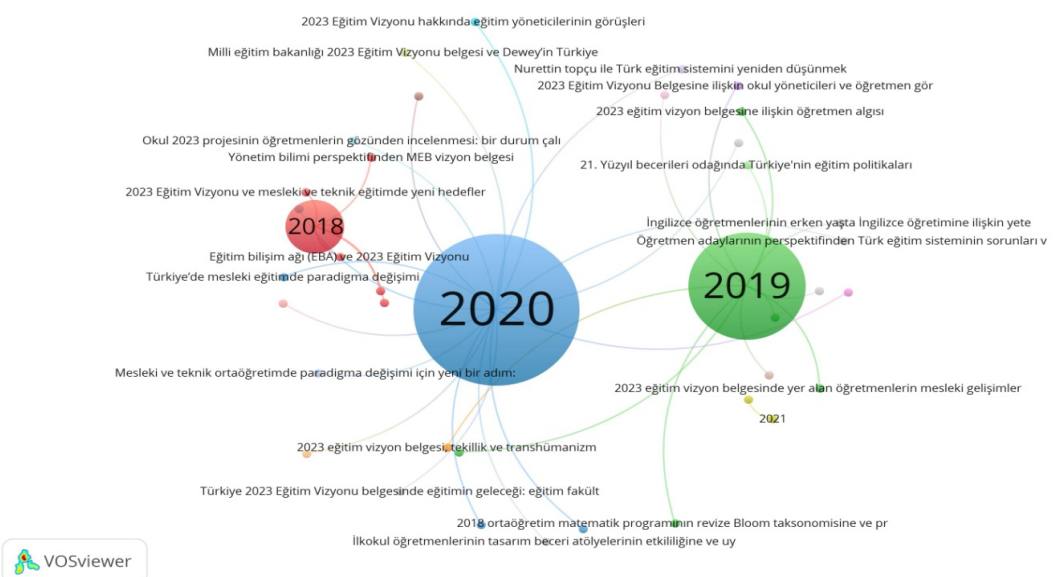

Şekil 1. Makalelerin Yayımlandığı Yıllara Göre Dağılımına İlişkin Ă̆ Haritası 


\section{Makalelerin Yayın Diline İlişkin Bulgular}

Tablo 3'te araştırma kapsamindaki makalelerden 32'sinin Türkçe ve 4'ünün ise İngilizce yayımlandığı görülmektedir. Buna göre makalelerin büyük bir çoğunluğu Türkçe yayımlanmıştır.

Tablo 3. Makalelerin Yayın Diline Göre Dağılımı

\begin{tabular}{lll}
\hline Yayın Dili & $\mathbf{f}(\mathbf{3 6})$ & $\%$ \\
\hline Türkçe & 32 & 89 \\
İngilizce & 4 & 11 \\
\hline
\end{tabular}

\section{Makalelerin Yayımlandıklan Dergilere İlişkin Bulgular}

Tablo 4'te araştırma kapsamındaki makalelerin en çok yayımlandığı 4 (dört) dergi görülmektedir. İncelenen 36 çalışma, 27 farklı dergide yayımlanmıştır. En çok makale yayımlanan Seta Perspektif Dergisi, Milli Eğitim Dergisi, Bolu İzzet Baysal Üniversitesi Eğitim Fakültesi Dergisi ve Eurasian Journal of Educational Research dergisi dışındaki diğer 23 derginin her birinde 1'er dergi yayımlanmıştır.

Tablo 4. Makalelerin Yayımlandıklam Dergilere Göre Dağılımı

\begin{tabular}{lll}
\hline Yayımlandığı Dergi & $\mathbf{f ~ ( 3 6 )}$ & \% \\
\hline Seta Perspektif Dergisi & 5 & 14 \\
Milli Ĕgitim Dergisi & 4 & 11 \\
Bolu İzzet Baysal Üniversitesi Eğitim Fakültesi Dergisi & 2 & 6 \\
Eurasian Journal of Educational Research & 2 & 6 \\
\hline
\end{tabular}

\section{Makalelerin Yazar Sayısına İlişkin Bulgular}

Tablo 5'te araştırma kapsamında incelenen yayınların yazar sayısına göre dağılımı görülmektedir. Buna göre makalelerden 16'si (\%44) iki yazarlı, 12'si (\%33) bir yazarlı, 5'i (\%14) dört ve üzeri yazarlı ve 3'ü (\%8) ise üç yazarlıdır. Makalelerin en çok iki yazarlı olduğu görülmektedir. Şekil 2'de makalelerin yazar sayısına göre yoğunlaştırılmış ağ haritası yer almaktadır. 
Tablo 5. Makalelerin Yazar Sayısına Göre Dağılımı

\begin{tabular}{lll}
\hline Yazar Sayısı & $\mathbf{f ( 3 6 )}$ & $\mathbf{\%}$ \\
\hline Bir yazarlı & 12 & 33 \\
İki yazarlı & 16 & 44 \\
Üç yazarlı & 3 & 8 \\
Dört ve Üzeri yazarlı & 5 & 14 \\
\hline
\end{tabular}

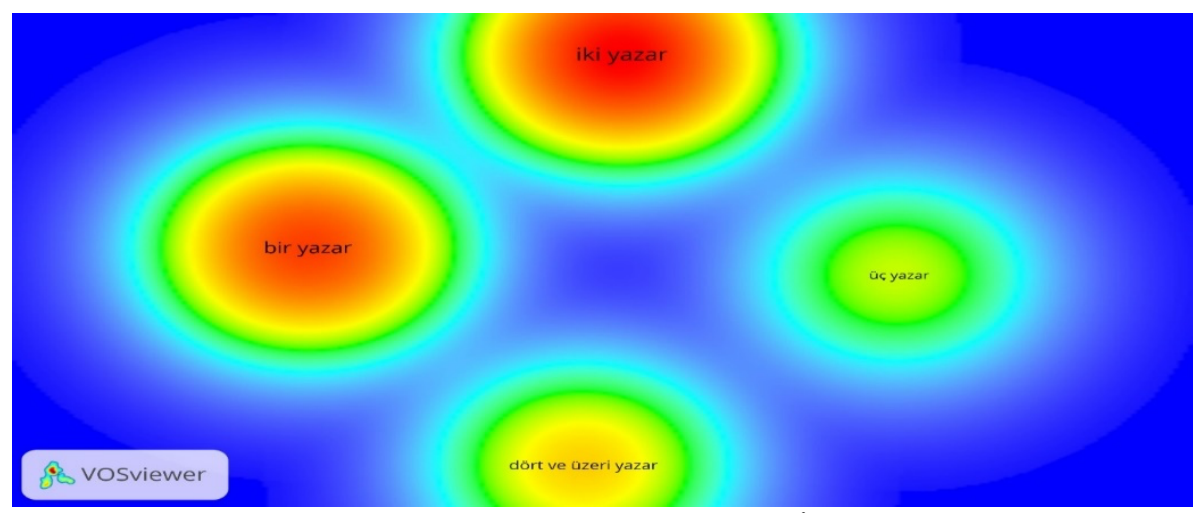

Şekil 2. Yayınların Yazar Sayısına Göre Dă̆ılımına İlişkin Yoğunlaştırılmış A $\breve{g}$

\section{Haritası}

\section{Makalelerde Kullanılan Anahtar Kelimelere İlişkin Bulgular}

Araştırma kapsamında incelenen makalelerde toplam 93 anahtar kelime kullanılmış; Tablo 6'da bunlardan 11'inin (\%12) "Eğitim Vizyonu”, 4'ünün (\%4) "öğretmen”, 4'ünün (\%4) “Eğitim Vizyon Belgesi” ve "eğitim”, "vizyon", “Mesleki ve Teknik Eğitim” ile “Türk Eğitim Sistemi” kelimelerinin ise 3'er (\%3) kez kullanıldığı görülmektedir. Şekil 3'te makalelerde kullanılan anahtar kelimelerin dağılımına ilişkin ağ haritası yer almaktadır.

\section{Tablo 6. Makalelerde Kullanılan Anahtar Kelimelerin Dağılımı}

\begin{tabular}{lll}
\hline Anahtar Kelime & $\mathbf{f ~ ( 9 3 )}$ & \% \\
\hline Eğitim Vizyonu & 11 & 12 \\
Öğretmen & 4 & 4 \\
Eğitim Vizyon Belgesi & 4 & 4 \\
Eğitim & 3 & 3 \\
Vizyon & 3 & 3 \\
Mesleki ve Teknik Eğitim & 3 & 3 \\
Türk Eğitim Sistemi & 3 & 3 \\
\hline
\end{tabular}




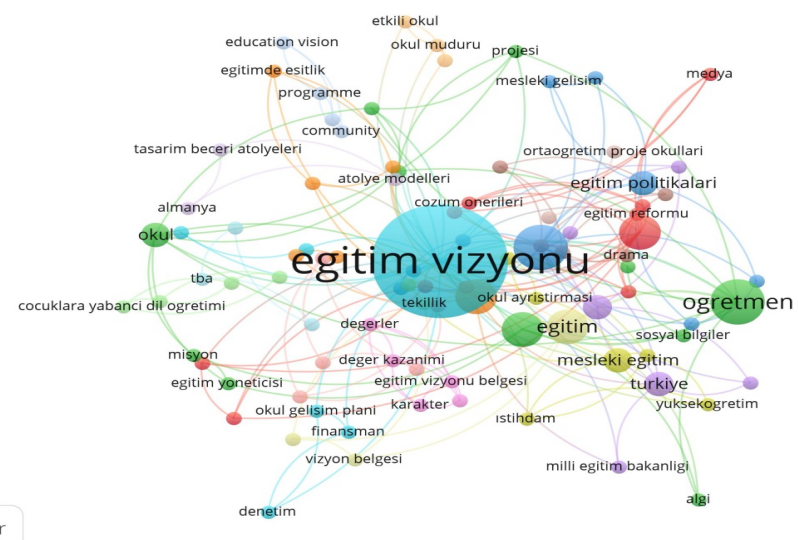

Şekil 3. Makalelerde Kullanılan Anahtar Kelimelerin Dă̆ılımına İlişkin A ̈̆ Haritası

\section{Makalelerin Atıf Sayısına İlişkin Bulgular}

Araştırma kapsamında incelenen yayınlarda toplam 1188, yayın başına ortalama yaklaşık 33 atıf yapıldığı tespit edilmiştir. Bu atıflardan 703'i yerli, 470'i yabanc ve $15^{\prime} \mathrm{i}$ ise yerli ve yabancı yazar iş birliği ile yapılan yayınlardır. Yayınların atıf sayısına göre dağılımlarının yer aldığı Tablo 7'de, makalelerden 18 'inde (\%50) 0-25, 8 'inde (\%22) 26-50, 6'sinda (\%17) 76 ve üzeri, 4 'ünde (\%11) ise 51-75 aralığında atıf bulunduğu görülmektedir. Şekil 4'te makalelerde yapılan atıf sayısının dağılımına ilişkin yoğunlaştırılmış ağ haritası yer almaktadır.

Tablo 7. Makalelerin Atıf Sayısına Göre Dağılımı

\begin{tabular}{lll}
\hline Atıf Sayısı & $\mathbf{f ( 3 6 )}$ & $\mathbf{\%}$ \\
\hline $0-25$ & 18 & 50 \\
$26-50$ & 8 & 22 \\
$51-75$ & 4 & 11 \\
76 ve üzeri & 6 & 17 \\
\hline
\end{tabular}




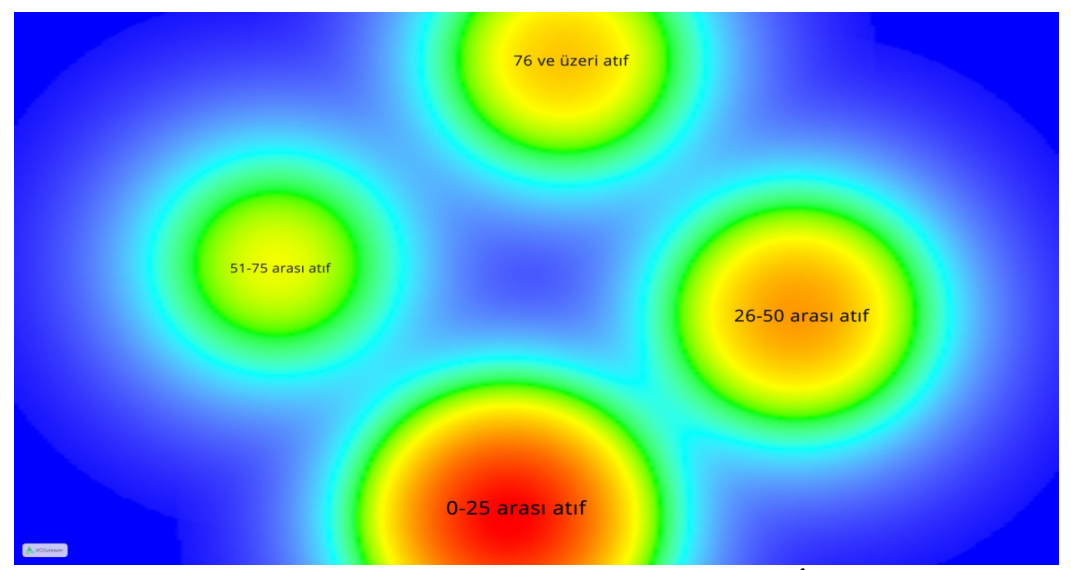

Şekil 4. Makalelerin Atıf Sayısına Göre Dă̆ılımına İlişkin Yoğunlaştırılmış A ğ Haritası

\section{Makalelerde En Çok Atıf Yapılan Yazar/Yazarlara İlişkin Bulgular}

Tablo 8'de makalelerde sıklıkla atıf yapılan yazar/kurumların Mahmut Özer, MEB, Ali Yıldırım, Hasan Şimşek, Hayri Eren Suna ve OECD olduğu görülmektedir. Şekil 5'te makalelerde sıklıkla atıf yapılan yazarların dağıl1mına ilişkin ağ haritası görülmektedir. Buna göre 2023 Eğitim Vizyon Belgesi ile ilgili yapılan çalışmalarda en çok atıf yapılan araştırmacılar Mahmut Özer, MEB, Ali Yıldırım, Hasan Şimşek, Hayri Eren Suna ve OECD’dir.

Tablo 8. Makalelerde En Çok Atıf Yapılan Yazar Dağılımı

\begin{tabular}{lll}
\hline Atıf Yapılan Yazar & $\mathbf{f ~ ( 1 1 8 8 )}$ & $\mathbf{\%}$ \\
\hline Mahmut Özer & 64 & 34 \\
MEB & 49 & 26 \\
Ali Yıldırım & 21 & 1 \\
Hasan Şimşek & 19 & 2 \\
Hayri Eren Suna & 17 & 1 \\
OECD & 15 & 1 \\
\hline
\end{tabular}




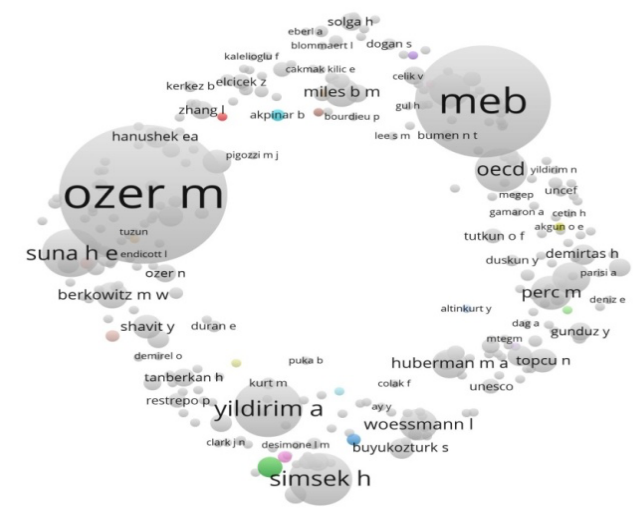

As vosviewer

Şekil 5. Makalelerde En Çok Atıf Yapılan Yazar Dă̆ılımına İlişkin A ̆̆ Haritası

\section{Makalelerde En Çok Atıf Yapılan Yayın/Yayınlara İlişkin Bulgular}

İncelenen makalelerde en çok atıf yapılan 12 yayın Tablo 9'da görülmektedir. Makalelerde toplam 1188 atıf yapılmıştır. 2023 Eğitim Vizyon Belgesine 38 makaleden 23'ünde atıf yapıldığı görülmektedir. Makalelerden 15'inde 2023 Eğitim Vizyon Belgesi ile ilgili olmasına rağmen atıf yapılmamasının sebebi çalışmalarda 2023 Eğitim Vizyon Belgesinden bahsedilmiş olmasına rağmen metin içi ya da kaynak kısmında atıfın belirtilmemiş olmasıdır. Makalelerin 17'sinde Ali Yıldırım Hasan Şimşek'in "Sosyal Bilimlerde Nitel Araştırma Yöntemleri" adlı kitabına; 9'unda Matthew B. Miles ve A. Michael Huberman.'in "Qualitative Data Analysis" isimli kitabına atif yapılmıştır. Bu yayınları "The 2023 Education Vision and new goals in vocational and technical education", "Background of problems in vocational education and training and its road map to solution in Turkey's Education Vision 2023", "Future of vocational and technical education in Turkey: Solid steps taken after Education Vision 2023", "Social and juristic challenges of artificial intelligence", "Restorasyon ve toparlanma dönemi: Mesleki ve teknik eğitimde 2000'li yıllar", "Dreams and realities of school tracking and vocational education", "Educational policy actions by the Ministry of National Education in the times of COVID-19 pandemic in Turkey"ve "Vocational education and training as 'A friend in need' during coronavirus pandemic in Turkey" başlıklı makaleler izlemektedir. 
Tablo 9. Makalelerde En Çok Atıf Yapılan Yayın Dağılımı

\begin{tabular}{|c|c|c|}
\hline Atıf Yapılan Yayın & $\mathbf{f}$ & $\%$ \\
\hline 2023 Eğitim Vizyon Belgesi & 23 & 1,94 \\
\hline Sosyal Bilimlerde Nitel Araştırma Yöntemleri & 17 & 1,43 \\
\hline Qualitative Data Analysis (Miles vd., 2014) & 9 & 0,76 \\
\hline $\begin{array}{l}\text { The } 2023 \text { Education Vision and new goals in vocational and tech- } \\
\text { nical education (Özer, 2018) }\end{array}$ & 4 & 0,34 \\
\hline $\begin{array}{l}\text { Background of problems in vocational education and training and } \\
\text { its road map to solution in Turkey's Education Vision } 2023 \text { (Özer, } \\
\text { 2019). }\end{array}$ & 4 & 0,34 \\
\hline $\begin{array}{l}\text { Reconsidering the fundamental problems of vocational education } \\
\text { and training in Turkey and proposed solutions for restructuring } \\
\text { (Özer, 2019) }\end{array}$ & 4 & 0,34 \\
\hline $\begin{array}{l}\text { Future of vocational and technical education in Turkey: Solid steps } \\
\text { taken after Education Vision } 2023 \text { (Özer ve Suna, 2019) }\end{array}$ & 4 & 0,34 \\
\hline Social and juristic challenges of artificial intelligence (Perc vd., 2019) & 4 & 0,34 \\
\hline $\begin{array}{l}\text { Restorasyon ve toparlanma dönemi: Mesleki ve teknik eğitimde } \\
\text { 2000'li yıllar (Özer vd., 2011). }\end{array}$ & 4 & 0,34 \\
\hline $\begin{array}{l}\text { Dreams and realities of school tracking and vocational education } \\
\text { (Özer ve Perc, 2020) }\end{array}$ & 4 & 0,34 \\
\hline $\begin{array}{l}\text { Educational policy actions by the Ministry of National Education in } \\
\text { the times of COVID-19 pandemic in Turkey (Özer, 2020c) }\end{array}$ & 4 & 0,34 \\
\hline $\begin{array}{l}\text { Vocational education and training as "A friend in need" during } \\
\text { coronavirus pandemic in Turkey (Özer, 2020d) }\end{array}$ & 4 & 0,34 \\
\hline
\end{tabular}

\section{Makalelerin Araştırma Yöntemine/Yaklaşımına/Örneklemine/Veri Top- lama Yöntemine İlişkin Bulgular}

Tablo 10'da çalışma kapsamında incelenen makalelerin araştırma yöntemlerine ilişkin bilgiler görülmektedir. Makalelerden 33'ünün (\%91) nitel, 2'sinin (\%6) nicel ve 1'inin (\%3) ise karma yöntemle yapılmış olduğu görülmektedir. Nitel araştırma yöntemlerinin kullanıldığı makalelerin 21'inin doküman incelemesi yöntemi, 9'unun durum çalışması ve 3 'ünün ise olgubilim yöntemi ile gerçekleştirildiği tespit edilmiştir.

Tablo 10. Makalelerin Araştırma Yöntemine Göre Dağılımı

\begin{tabular}{lllll}
\hline Araştırma Yöntemi & & $\mathbf{f ( 3 6 )}$ & $\mathbf{\%}$ \\
\hline Nitel & Doküman İncelemesi & 21 & & 91 \\
& Durum Çalışması & 9 & 33 & \\
Nicel & Olgubilim & 3 & & 6 \\
& Betimsel & 1 & 2 & 1 \\
Karma & İlişkisel & 1 & & 1 \\
\hline
\end{tabular}


Tablo 11'de çalışma kapsamında incelenen makalelerde benimsenen araştırma yaklaşımına ve örneklem sayısına ilişkin bilgiler görülmektedir. İncelenen 36 makaleden 21'inde (\%58) kuramsal araştırma yaklaşımı, 15 'inde (\%42) ise görgül araştırma yaklaşımı kullanılması çalışmalarda dikkat çeken bir diğer noktadır. Görgül araştırma yaklaşımı ile yapılan bu 15 makalede örneklem grubu olarak yönetici, öğretmen, öğrenci ve öğretim üyelerinin seçildiği, örneklem sayılarının çoğunlukla 1-30 aralığında olduğu tespit edilmiştir.

Tablo 11. Makalelerin Araştırma Yaklaşımı ve Örneklemine Göre Dağılımı

\begin{tabular}{|c|c|c|c|c|c|}
\hline Araştırma Yöntemi & & & & $f(36)$ & $\%$ \\
\hline \multirow[t]{3}{*}{ Kuramsal Yaklaşım } & & & & 21 & 58 \\
\hline & Örneklem Sayısı & $\mathrm{f}(\mathbf{1 5})$ & $\%$ & & \\
\hline & $1-30$ & 10 & 67 & & \\
\hline \multirow[t]{3}{*}{ Görgül Yaklaşım } & $31-60$ & 1 & 7 & 15 & 42 \\
\hline & $61-90$ & 1 & 7 & & \\
\hline & $91-80$ & 3 & 20 & & \\
\hline
\end{tabular}

Tablo 12'de nitel araştırma yönteminin kullanıldığı 33 makaleden 21'inde (\%58) doküman inceleme, 12'sinde (\%33) ise görüşme tekniği kullanılarak verilerin toplandığ1 görülmektedir. Nicel araştırma yöntemi ile gerçekleştirilen 3 (\%8) çalışmada ise Likert ölçek ile veriler toplanmıştır.

Tablo 12. Makalelerin Veri Toplama Tekniklerine Göre Dağılımı

\begin{tabular}{lll}
\hline Örneklem Sayısı & $\mathbf{f ( 3 6 )}$ & $\mathbf{\%}$ \\
\hline Doküman İnceleme & 21 & 58 \\
Görüşme & 12 & 33 \\
Likert Ölçek & 3 & 8 \\
\hline
\end{tabular}

Makalelerin Konu Alanlarına İlişkin Bulgular

Makalelerde 2023 Eğitim Vizyon Belgesinin hangi açlardan ele alınarak incelendiğine dair konu dağılımları Tablo 13'te görülmektedir. 2023 Eğitim Vizyon Belgesinin birçok konu alanı açısından, özellikle 6 (\%17) makalede "2023 Eğitim Vizyon Belgesinin genel değerlendirmesi ve uygulanabilirliği", 5 (\%14) makalede "mesleki eğitim", 3 (\%8) makalede "eğitim yönetimi/yöneticiliği" ve $3(\% 8)$ makalede "tasarım ve beceri atölyeleri" konuları açısından ele alındığı görülmektedir. 
Tablo 13. Makalelerin Konu Alanlarına Göre Dağılımı

\begin{tabular}{|c|c|c|}
\hline Konu Alanı & $f(36)$ & $\%$ \\
\hline 2023 Eğitim Vizyon Belgesi & 23 & 1,94 \\
\hline Sosyal Bilimlerde Nitel Araştırma Yöntemleri & 17 & 1,43 \\
\hline Qualitative Data Analysis (Miles vd., 2014) & 9 & 0,76 \\
\hline $\begin{array}{l}\text { The } 2023 \text { Education Vision and new goals in vocational and tech- } \\
\text { nical education (Özer, 2018) }\end{array}$ & 4 & 0,34 \\
\hline $\begin{array}{l}\text { Background of problems in vocational education and training and } \\
\text { its road map to solution in Turkey's Education Vision } 2023 \text { (Özer, } \\
\text { 2019). }\end{array}$ & 4 & 0,34 \\
\hline $\begin{array}{l}\text { Reconsidering the fundamental problems of vocational education } \\
\text { and training in Turkey and proposed solutions for restructuring } \\
\text { (Özer, 2019) }\end{array}$ & 4 & 0,34 \\
\hline $\begin{array}{l}\text { Future of vocational and technical education in Turkey: Solid steps } \\
\text { taken after Education Vision } 2023 \text { (Özer ve Suna, 2019) }\end{array}$ & 4 & 0,34 \\
\hline Social and juristic challenges of artificial intelligence (Perc vd., 2019) & 4 & 0,34 \\
\hline $\begin{array}{l}\text { Restorasyon ve toparlanma dönemi: Mesleki ve teknik eğitimde } \\
\text { 2000'li yıllar (Özer vd., 2011). }\end{array}$ & 4 & 0,34 \\
\hline $\begin{array}{l}\text { Dreams and realities of school tracking and vocational education } \\
\text { (Özer ve Perc, 2020) }\end{array}$ & 4 & 0,34 \\
\hline $\begin{array}{l}\text { Educational policy actions by the Ministry of National Education in } \\
\text { the times of COVID-19 pandemic in Turkey (Özer, 2020c) }\end{array}$ & 4 & 0,34 \\
\hline $\begin{array}{l}\text { Vocational education and training as "A friend in need" during } \\
\text { coronavirus pandemic in Turkey (Özer, 2020d) }\end{array}$ & 4 & 0,34 \\
\hline
\end{tabular}

\section{Tartışma ve Sonuç}

2018 yılında yayımlanan 2023 Eğitim Vizyon Belgesi ile ilgili Ocak 2021 tarihine kadar yayımlanan 36 makalenin çeşitli parametreler açısından incelenmesi amacıyla gerçekleştirilen bu çalışmanın sonuçları alanyazınla tartışılarak aşağıda sunulmuştur.

Millî Eğitim Bakanlığınca 23 Ekim 2018 tarihinde kamuoyuna sunulan ve uygulamaya konulan 2023 Eğitim Vizyon Belgesinin hemen aynı yıl içinde bilimsel çalışmalara konu olduğu tespit edilmiştir. Araştırmaya dahil edilen 36 makaleden 6'sının 2018 yılında yayımlandığı, 2019 ve 2020 yıllarında da araştırmaların yoğunlukla devam ettiği belirlenmiştir. Vizyon Belgesi, eğitim sistemi içerisindeki tüm paydaşları bir şekilde heyecanlandırmış (Sözer, 2019) ve birçok araştırmacıya göre eğitim sisteminde yıllardır beklenen sorunların çözümü için umut verici bir adım olmuştur (Emin, 2018; Ertürk, 2020; Minaz ve Dikmen, 2019; Dayığlu Öcal ve İşcan, 2020; Sözer, 
2019; Taş, 2018). Nitekim Türkiye'de son yıllarda eğitim sisteminin toplumun beklentilerine ve çağın gereklerine cevap veremediği (Türk Eğitim-Sen, 2018), eğitimin sınıf geçmeye, sınavları kazanmaya ve iş bulmaya odaklandığı (MEB, 2018) ve sistemsizlik, düzensizlik tartışmalarına yönelik eleştirilerin (Baltacı ve Coşkun, 2019) varlığı dikkat çekmektedir.

Araştırmaya dahil edilen 36 makaleden büyük çoğunluğunun yayın dilinin Türkçe olduğu ve makalelerin 27 farklı dergide yayımlandığ1 tespit edilmiştir. 2023 Eğitim Vizyon Belgesi ile ilgili makalelerin farklı birçok dergide yayımlanarak alanyazına katkı sağladığı söylenebilir. Bilimsel dergiler bilimin gelişmesi ve ayrıca bilimsel alanda yapılan gelişmelerin yakından takip edilmesi açısından önemlidir (Gökçen ve Arslan, 2019). Yurtsever (2018)'e göre yapılan çalışmaların yayımlandıkları dergiler ve yayın sayısı o konuda yapılan çalışmaların kronolojik gelişiminin anlaşılmasında önemli bir veridir.

Araştırmaya dahil edilen 36 makalenin bir yazarlıdan ziyade iki, üç, dört ve üzeri yazarlı olduğu tespit edilmiştir. Bunun sebebi araştırmacıların birbirilerinin bilgi birikimlerinden yararlanmak istemeleri olabilir. Bu sonuç alanyazında yapılan bibliyometrik çalışmalarda incelenen makalelerin büyük çoğunluğunun çok yazarlılık durumu sergilediği sonucu ile örtüşmektedir (Boyraz ve Sandıkçı, 2018; Bozdemir ve Çivi, 2019; Sökmen ve Özkanlı, 2018; Temizkan vd., 2015). Yeksan ve Akbaba (2019)'ya göre makalelerin birden çok yazarlı olmasının sebeplerinin araştırmacıların birbirilerinin bilgi ve tecrübelerinden yararlanma çabaları ve nitelikli bir makale için uzun bir zamana ihtiyaç duyulması dolayısıyla zamanı daha verimli kullanmak üzere iş birliği yapmaya ihtiyaç duymalarıdır. Böylece iki veya daha fazla bilim insanı karşılıklı olarak görev paylaşımı yaparak bilimsel yayını tamamlar (Sayğan Tunçay ve Sürgevil Dalkılıç, 2017). Diğer taraftan alanyazında yapılan bibliyometrik çalışmalarda incelenen makalelerin çoğunluğunun tek yazarlı olduğu sonuçları mevcut araştırmanın sonuçları ile farklılaşmaktadır (Becerikli, 2013; Çiçek ve Kozak, 2012; Güner Yıldız vd, 2016; Karagöz ve Şeref, 2019a; Kozak, 1994; Şeref ve Karagöz, 2019; Yalçın, 2010; Wang ve Ho, 2017; Zan, 2013).

Araştırma kapsamındaki makalelerde yer alan anahtar kelimeler incelendiğinde; makalelerde toplam 93 anahtar kelime kullanıldığı belirlenmiştir. Ayrıca bu anahtar kelimelerden sadece 31'inin tekrarlandığı; tekrarlanan anahtar kelimelerin "Eğitim Vizyonu”, “öğretmen”, "Eğitim Vizyon Belge- 
si", "eğitim", “vizyon”, “Mesleki ve Teknik Eğitim" ve "Türk Eğitim Sistemi" olduğu tespit edilmiştir. Bu veriden hareketle çalışmalarda 2023 Eğitim Vizyon Belgesinin farklı açlardan ele alındığı söylenebilir. Alkan ve diğerlerine (2020) göre anahtar kelimeler yayınların içeriğinin özetlenmesini sağlamakla birlikte konu ile ilgili sıkça değinilen konu ve kavramlara ortaya koymaktadır. Ayrıca anahtar kelimeler ilgili yayınların arama motorları ve yayın dizinlerinde daha kolay bulunmasını ve dolayısıyla daha görünür olmasını sağlar (Springer, 2017).

Araştırmaya dahil edilen makalelerde yerli ve yabancı ortalama makale başına yaklaşık 33 atıf yapıldığı; üzerinde yapılan çalışma olması sebebiyle en çok "2023 Eğitim Vizyon Belgesi"ne atıf yapıldığı tespit edilmiştir. Lv ve diğerlerine (2011) göre atıf sayısı bir yayının etkisinin ve görünürlüğünün bir ölçüsüdür. Bunun yanında Ali Yıldırım ve Hasan Şimşek' in "Sosyal Bilimlerde Nitel Araştırma Yöntemleri" adlı kitabına; Matthew B. Miles ve A. Michael Huberman'ın "Qualitative Data Analysis" isimli kitabına atıf yapılmıştır. Bu yayınları "The 2023 Education Vision and new goals in vocational and technical education", "Background of problems in vocational education and training and its road map to solution in Turkey's Education Vision 2023", "Future of vocational and technical education in Turkey: Solid steps taken after Education Vision 2023", "Social and juristic challenges of artificial intelligence", "Restorasyon ve toparlanma dönemi: Mesleki ve teknik eğitimde 2000'li ylllar", "Dreams and realities of school tracking and vocational education", "Educational policy actions by the Ministry of National Education in the times of COVID-19 pandemic in Turkey"ve "Vocational education and training as 'A friend in need' during coronavirus pandemic in Turkey" başlıklı makaleler izlemektedir. En çok atıf yapılan yazar/kurumların ise Mahmut Özer, MEB, Ali Yıldırım, Hasan Şimşek, Hayri Eren Suna ve OECD olduğu saptanmıştır. Mahmut Özer ağ bilimi, eğitim politikası, mesleki ve teknik eğitim ve yükseköğretim; Hayri Eren Suna ise eğitim politikaları, ölçme ve değerlendirme ve mesleki ve teknik eğitim konuları üzerine çalışmalar yürütmektedir (Özer ve Suna, 2020) Millî Eğitim Bakanlığına yapılan atıfların 38'i 2023 Eğitim Vizyon Belgesine yapılan atıflardır. Ayrıca makalelerde Ekonomik İş birliği ve Kalkınma Örgütünün (OECD) gerçekleştirdiği küresel eğitim araştırmalarına da atıflar bulunmaktadır. Ali Yıldırım ve Hasan Şimşek'in yazdığı "Sosyal Bilimlerde Nitel Araştırma Yöntemleri" adlı kitap alanyazında yapılan nitel araştırmalarda 
sıklıkla başvurulan bir kaynaktır. İncelenen makalelerin büyük bir çoğunluğunun nitel çalışmalar olması, Ali Yıldırım ve Hasan Şimşek'in en çok atıf yapılan yazarlar arasında yer almasının sebebidir. Tüm bu verilerden hareketle atıf yapılan bu çalışmaların ve yazarlarının 2023 Eğitim Vizyon Belgesi ile ilgili alanyazına yön veren yayınlar ve araştırmacılar oldukları, bundan sonra bu konuda çalışma gerçekleştirecek araştırmacıların söz konusu araştırmacılara ve kaynaklara başvurulabileceği söylenebilir. Karagöz ve Şeref (2019a)'e göre literatüre yön veren kaynaklar bilimsel köprü işlevi görür ve bu kaynakların taranması ile üretilen yeni akademik yayınlar nitelikli birer yayin olur.

Araştırma kapsamındaki makalelerin çok büyük çoğunluğunun nitel yöntem ile gerçekleştirildiği belirlenmiştir. Nitel araştırmalar araştırılan konuya ilişkin katılımcllardan alınan görüşlerin derinlemesine bilgi edinerek anlaşılmasını sağlar (Yıldırım ve Şimşek, 2018). Alanyazında yapılan bibliyometrik çalışmalarda incelenen makalelerin çoğunlukla nitel araştırma yöntemi ile gerçekleştirildiğinin tespit edildiği çalışmalara rastlanmaktadır (Bitirim Okmeydan, 2020; Cengiz, 2019; Tayfun vd., 2018). Öte yandan daha çok nicel araştırma yöntemlerinin tercih edildiği makalelerin olduğu ve bu çalışmanın sonucu ile örtüşmeyen çalışmalar da mevcuttur (Erdoğan vd., 2015; Göktaş vd., 2019; Gül ve Sözbilir, 2015; Kanlı vd., 2014; Polat Üzümcü, 2019; Tayfun vd., 2018; Varışoğlu vd., 2013; Yılmaz, 2017).

Araştırma kapsamındaki makalelerde görgül araştırma yaklaşımından çok kavramsal araştırma yaklaşımı benimsendiği saptanmıştır. Alanyazında bu sonuçla örtüşen bibliyometrik çalışmalara rastlanmaktadır (Akgün ve Karataş, 2017; Kartal, 2018; Kozak, 1994; Kozak, 1995); bu sonuç ile örtüşmeyen çalışmalara da rastlanmaktadır (Ayaz ve Türkmen, 2017; Aydın, 2017; Çarıkçı ve Yaman, 2019; Kaygalak Çalebi ve Kurlar ve Cac, 2019; Sünnetçioğlu vd., 2017; Tayfun vd., 2018; Y1lmaz, 2017; Zencir ve Kozak, 2012). Görgül araştırmalar, verilerin anket, gözlem ve görüşme yöntemleri ile elde edildiği araştırmalardır. Kavramsal çalışmaların varlığı, ilgili bilim dalının ya da disiplinin nitelik kazanması açısından önemlidir (Adom vd., 2018). Diğer taraftan Koppl (2007)'a göre de görgül araştırmalar bilimsel bilginin ilerlemesine önemli bir katkı sağlar. Bu anlamda 2023 Eğitim Vizyon Belgesi ile ilgili yapılan kavramsal çalışmaların yanında görgül araştırmalar ile gözlemlenebilir bir şekilde var olan durumun ortaya konularak bilimsel olarak değerlendirilmesi önemlidir. 2023 Eğitim Vizyon Belgesinin eğitim paydaş- 
ları tarafından farklı bakış açılarıyla değerlendirilmesi, yeterliklerinin uygulayıcıların gözünden belirlenmesi hem elde edilen görgül verilerin ve sonuçların kavramsal bilgiler ile ilişkilendirilmesi ve açıklanmasına olanak sağlayacak hem de uygulamada karşılaşlabilecek sorunların tespit edilmesi ve giderilmesi mümkün olacaktır.

Araştırma kapsamında incelenen ve görgül araştırma yaklaşımı ile gerçekleştirilen makalelerde örneklem grubu olarak yönetici, öğretmen ve öğrencilerin seçilmiş olduğu tespit edilmiştir. Eğitim sistemine yönelik iyileştirici ve geliştirici hedefleri içeren Vizyon Belgesinin özellikle sistemin başat rol oynayıcısı yönetici ve öğretmenler tarafından nasıl görüldügünün, ne kadar benimsendiğinin ve görüşlerinin belirlenmesi hedeflerin gerçekleştirilmesi, planlanan çalışmaların uygulanması ve istenilen verimin elde edilebilmesi açısından önemlidir. Öte yandan Vizyon Belgesinde söz konusu hedeflerin tüm paydaşlarla birlikte başarılacağı vurgusu yapılmaktadır (MEB, 2018). Barton ve Walker (2017)'a göre eğitim sistemlerinin başarısı, eğitim politikaları kararlarını alanlar ile bu politikaları uygulayanlar arasındaki uyumu gerektirir. Bu nedenle belgenin çeşitli paydaşlarca eleştirilmesi, tartışılması, konu ile ilgili etkili iletişim çalışmalarının yürütülmesi belgenin paydaşlarca sahiplenilmesi ve benimsenmesi açısından önemlidir (Eğitim Reformu Girişimi, 2018).

Araştırma kapsamında incelenen ve görgül araştırma yaklaşımı ile gerçekleştirilen makalelerin çoğunlukla 1-30 aralığındaki örneklem büyüklüğü ile gerçekleştirildiği tespit edilmiştir. Nitel araştırmaların genellikle az say1da katılımcı ile yapılması (Yıldırım ve Şimşek, 2018) bu araştırmanın sonucunu açıklar niteliktedir. Ayrıca makalelerde veri toplama yöntemi olarak görüşme tekniği kullanıldığı belirlenmiştir. Görüşme tekniği nitel araştırmalarda sıklıkla kullanılan bir veri toplama tekniğidir (Yıldırım ve Şimşek, 2018). Alanyazında yapılan bibliyometrik çalışmalarda incelenen makalelerde veri toplama yöntemi olarak çoğunlukla görüşme tekniğinin kullanıldığının tespit edildiği çalışmalara rastlanmaktadır (Cengiz, 2019; Saban, 2009; Saban vd., 2010). Öte yandan bu çalışmanın sonucu ile örtüşmeyen çalışmalar da mevcuttur (Doğru vd., 2012; Selçuk vd., 2014; Gül ve Sözbilir, 2015; Tayfun vd., 2018; Sünnetçioğlu vd., 2017). Bu çalışmalarda çoğunlukla anket tekniğinden yararlanılmıştır.

Araştırma kapsamındaki makalelerin konu alanlarına göre yönelimleri değerlendirildiğinde; makalelerde 2023 Eğitim Vizyon Belgesinin “2023 
Eğitim Vizyon Belgesinin genel değerlendirmesi ve uygulanabilirliği "mesleki eğitim", "eğitim yönetimi/yöneticiliğii" ve "tasarım ve beceri atölyeleri" daha çok olmak üzere farklı konu alanları açısından ele alındığı tespit edilmiştir. Bu durumda belgenin farklı açılardan makalelere konu olduğu ve dolayısıyla farklı açılardan değerlendirildiği söylenebilir. Öte yandan Türk Eğitim Sisteminin her kademesini ilgilendiren önemli kararların alındığı kapsamlı bir planlama ve sürdürülebilir bir yol haritası özelliğinde olan 2023 Eğitim Vizyon Belgesinde eğitim vizyonu felsefesi, temel politika, içerik ve uygulama ve okul gelişimi, veriye dayalı bir yönetim sisteminin oluşturulması, ölçme değerlendirme, insan kaynaklarının geliştirilmesi, okulların finansmanı, teftiş sistemi gibi eğitimin yönetimi ile ilgili bölümler ve rehberlik ve psikolojik danışmanlık hizmetleri, özel eğitim, özel yetenek, yabanc dil eğitimi, öğrenme süreçlerinde dijital içerik ve beceri destekli dönüşüm, okulöncesi, temel eğitim, ortaöğretim, Fen ve Sosyal Bilimler Liseleri, İmam Hatip Okulları, mesleki ve teknik eğitim ve hayat boyu öğrenmeye yönelik hedeflere yer verilmiştir (MEB, 2018). Bu konu alanlarının birçoğunun incelenen makaleler kapsamında henüz akademik çalışmalara konu olmadığı dikkat çekmektedir. Vizyon Belgesi çok yönlü bir bakış açısıyla eğitim sisteminin gelişimini destekleyen yeniliklere açı bir eğitim felsefesine vurgu yapmaktadır (Baltacı ve Coşkun, 2019). Bu yönü ile akademik çalışmalar ile eğitim sistemindeki sorunların vizyon belgesi çerçevesinde ele alınarak değerlendirilmesi ve belgenin uygulanması sürecinde karşılaşılabilecek zorlukların belirlenmesinin, politika belirleyicilerine rehberlik etmesi açısından önem arz etmektedir. Bu nedenle belgede yer alan tüm konu başlıklarının akademik olarak ele alınmasını sağlamak üzere daha çok çalışma yapılabilir. Murathan ve diğerlerine (2020) göre bir konuda yapılan akademik çalışmalar, o konu hakkında kapsamlı bir durum tespitine imkân sağlayacaktır. Sözer (2019)'e göre Vizyon Belgesi ile ilgili yapılan akademik çalışmalar, belgenin uygulanmasında gerçekleşmesi muhtemel sorunların belirlenmesi ve bu yönde yapılan öneriler ile yapılabilecek iyileştirme çalışmaları açısından önemlidir.

\section{Öneriler}

Çalışmanın en önemli sınırlılığı analize dâhil edilen makalelerin DergiPark ve ResearchGate veri tabanlarından alınmasıdır. Gelecek çalışmalarda farklı 
veri tabanlarından elde edilen makalelerin, bildirilerin analiz edileceği çalışmalar yapılabilir. Araştırmaya dahil edilen makalelere 02.01.2021 tarihinde ulaşılmıştır. Bu tarihten sonra veri tabanına eklenen makaleler ile analiz sonuçları değişebilir. Bu nedenle farklı zamanlarda çalışma tekrarlanabilir. Yeni yapılacak çalışmalarda farklı bir parametre olarak atıf analizi gerçekleştirilebilir.

Araştırma kapsamındaki makalelerin büyük çoğunluğunun doküman incelemesi ve görüşme tekniği kullanılarak nitel yöntem ile gerçekleştirildiği belirlenmiştir. Öte yandan nicel veriler ile mevcut problemlerin tanımlanması daha genel bir bakış açısıyla tanımlanması mümkündür (Karasar, 2017) Bu nedenle daha fazla nicel çalışmalar yapılarak 2023 Eğitim Vizyon Belgesi ile ilgili mevcut problemlerin saptanması ve büyük örneklem grupları ile genellemeler yapılması sağlanabilir. Gaur ve diğerlerine (2014) göre bir araştırmada doğru sonuçlara ulaşmak için tek bir yöntemin kullanılması yeterli değildir. Bu nedenle nitel ve nicel yöntemin birlikte kullanıldığı karma yöntem ile yapılan çalışmalar ile daha iyi sonuçlar elde edilebilir.

Araştırmada analiz edilen makaleler kapsamında Vizyon Belgesinde yer alan konu alanlarının birçoğunun henüz ele alınmaması doldurulması gereken bir boşluk ve tamamlanması gereken bir eksiklik olarak değerlendirilmelidir. Vizyon Belgesinde yer alan okul gelişim modeli, veriye dayalı yönetim sistemi, ölçme değerlendirme, insan kaynaklarının geliştirilmesi, okulların finansmanı, teftiş sistemi, rehberlik ve psikolojik danışmanlık hizmetleri, özel eğitim, özel yetenek, temel eğitim, ortaöğretim, Fen ve Sosyal Bilimler Liseleri, İmam Hatip Okulları ve hayat boyu öğrenmeye yönelik konularda çalışmalar yapılmalıdır. Çalışma, 2023 Eğitim Vizyon Belgesi ile ilgili yapılan çalışmaların yönünü ve eğilimlerini göstermesi açısından araştırmacılara yol gösterebilir ve bundan sonra yapılacak çalışmalarda yararlanulacak bir kaynak olabilir. 


\title{
EXTENDED ABSTRACT
}

\section{Reflections of the 2023 Educational Vision on Academic Studies: A Bibliometric Analysis}

\author{
Çiğdem Ayanoğlu - Tanju Demir - Duygu Gür Erdoğan \\ Hacettepe University -Sakarya University
}

The 2023 Education Vision Document, which includes the basic vision adopted for the education system in Turkey, the philosophical foundations of this vision and the targets that the Ministry of National Education plans to achieve until 2023, was published on October 23, 2028. It has been stated that the document came to the fore due to the need for paradigmatic transformation in education and its main purpose is to raise moral individuals who have contemporary skills and competencies, who work for the benefit of humanity, who value science and culture. The objectives in the document, which was prepared with the main objective of providing a breakthrough in quality and a sustainable roadmap in education in the medium term, are design and pioneering piloting in the 2018-2019 academic year; Piloting and implementation across the country in the 2019-2020 academic year; It is planned to be completed with the realization of all objectives in the 2020-2021 academic year (MEB, 2018).

The 2023 Education Vision Document emphasizes a radical change that will affect a long period of time. For this reason, it can be thought that the vision document is a start for a long-term future goal and is open to development and revision. At this point, it can be said that the academic studies on the 2023 Education Vision Document can contribute quite a lot to this development and revision. Summarizing the points examined and the results obtained in the researches is important in terms of allowing a holistic perspective to be formed. For this purpose, bibliometric analysis of 36 publications related to the 2023 Education Vision Document, which has been made and accessed within the scope of the research, has been carried out in terms of various parameters. With this study, it was ensured that an objective general evaluation based on data was made by obtaining information about the amount and scope of scientific information produced about the Education Vision Document, determining which points of the subject were 
focused on and which points were less discussed. It is hoped that these evaluations will provide data to the Ministry of National Education regarding applications, improvements or new regulations, will guide the educational scientists in the direction of studies that have not been sufficiently emphasized yet, and will shed light on the field and contribute to the field by revealing the profile of the researches made up to now.

The research is designed in descriptive research model and is a qualitative research based on document analysis method. The data used in the research were obtained from the articles accessed on 02.01.2021 from the DergiPark and ResearchGate databases, which provide editorial services and present academic refereed journals published in Turkey under the umbrella of TÜBITAK ULAKBIM. Search was carried out in the databases with the word groups "2023 Eğitim Vizyonu”, "Eğitim 2023 Vizyonu”, "2023 Eğitim Vizyon" "2023 Education Vision", title, keywords and abstract.

It was determined that 6 of the 36 articles included in the research were published in 2018, and the researches continued intensively in 2019 and 2020. The Vision Document has somehow excited all the stakeholders in the education system (Sözer, 2019) and according to many researchers, it has been a promising step in solving the problems that have been expected in the education system for years (Emin, 2018; Ertürk, 2020; Minaz and Dikmen, 2019; Dayığlu Öcal and İşcan, 2020; Sözer, 2019; Taş, 2018). When the keywords in the articles within the scope of the research are examined; It was determined that a total of 93 keywords were used in the articles. In addition, only 31 of these keywords were repeated; It has been determined that the repeated keywords are "Education Vision", "teacher", "Education Vision Document", "education", "vision", "Vocational and Technical Education" and "Turkish Education System". Based on this data, it can be said that the 2023 Education Vision Document is handled from different perspectives in the studies. According to Alkan et al. (2020), keywords provide a summary of the content of the publications and reveal frequently mentioned topics and concepts related to the subject. In addition, keywords make related publications easier to find in search engines and publication directories and therefore more visible (Springer, 2017). It was determined that the vast majority of the articles within the scope of the research were carried out with the qualitative method. Qualitative research provides in-depth knowledge and understanding of the views received from the participants 
on the subject under investigation (Yıldırım \& Şimşek, 2018). In the articles within the scope of the research, it was determined that the conceptual research approach was adopted rather than the empirical research approach. It was determined that administrators, teachers and students were chosen as the sample group in the articles examined within the scope of the research and carried out with the empirical research approach. How the Vision Document, which includes remedial and developmental goals for the education system, is seen especially by the administrators and teachers who play the leading role of the system, how much it is adopted and its views are important in terms of realizing the goals, implementing the planned studies and achieving the desired efficiency.

\section{Kaynakça/References}

Adom, D., Hussein, K. E. and Agyem, J. A. (2018). Theoretical and conceptual framework: Mandatory ingredients of a quality research. International Journal of Scientific Research, 7(1), 438-445.

Akbaş, E. E. ve Çavuş, H. (2020). Evaluation of digital content-supported transformation from teachers' perspectives within the scope of 2023 Education Vision. Educational Policy Analysis and Strategic Research, 15(3), 290-309. http://doi.org/ 10.29329/epasr.2020.270.14

Akgün, B. ve Karataş, B. (2017). Muhasebe ve denetime bakış dergisinde yayımlanan makalelerin bibliyometrik analizi (2000-2016). Muhasebe ve Denetime Bakış Dergisi, 17(52), 19-34.

Akyildiz, S., Filizz, T. ve Kayser, V. (2019a). Okul müdürlerinin 2023 eğitim vizyon belgesinde yer alan yöneticilerin mesleki gelişimlerine ilişkin düzenlemelere yönelik görüşlerinin incelenmesi. Milli Eğitim Dergisi, Temel Eğitim Özel Sayısı, 793-826.

Akyıldız, S., Yurtbakan, E. ve Tok, R. (2019b). 2023 Eğitim Vizyon Belgesinde yer alan öğretmenlerin mesleki gelişimleri ile ilgili politikaların öğretmen görüşlerine göre değerlendirilmesi. Milli Eğitim Dergisi, Temel Ĕ̆itim Özel Sayısı, 827-852.

$\mathrm{Al}$, U. ve Coştur, R. (2007). Türk Psikoloji Dergisi'nin bibliyometrik profili. Türk Kütüphaneciliği, 21(2), 142-163.

Alkan, G., Yilmaz, B. ve Oğuz, S. (2020). Tersine lojistik alanındaki yayınların bibliyometrik analiz yöntemiyle değerlendirilmesi. Atatürk Üniversitesi İktisadi ve İdari Bilimler Dergisi, 34(3), 711-729. 
Alkoç, G. P. (2010). Misyon ve vizyon ifadelerinin işletme stratejisindeki yeri ve işletme performansı üzerindeki etkileri. Yüksek Lisans Tezi. Sosyal Bilimler Enstitü, İşletme Yönetimi ve Organizasyon Bilim Dalı, İstanbul Üniversitesi.

Arkan, A. ve Karaboğa, K. (2018). Yönetim bilimi perspektifinden MEB Vizyon Belgesi. Seta Perpektif, 215.

Arkan, A. ve Kaya, E. (2018). Eğitim Bilişim Ağ1 (EBA) ve 2023 Eğitim Vizyonu. Seta Perpektif, 221.

Arkan, A. ve Öztürk, N. (2018). 2023 Eğitim Vizyonu'nda erken çocukluk eğitimi. Seta Perpektif, 218.

Artsın, M. (2020). Bir metin madenciliği uygulaması: Vosviewer. Eskişehir Teknik Üniversitesi Bilim ve Teknoloji Dergisi B- Teorik Bilimler, 8(2), 344-354.

Ayaz, N., ve Türkmen, B. M. (2018). Yöresel yiyecekleri konu alan lisansüstü tezlerin bibliyometrik analizi. Gastroia: Journal of Gastronomy And Travel Research, 2(1), 22-38.

Aydın, B. (2017). Yükseköğretim kurulu tez merkezinde (YÖKTEZ) yiyecek içecek işletmeciliği alanında kayıtlı bulunan tezlerin bibliyometrik analizi. Disiplinlerarası Akadamik Turizm Dergisi, 2(1), 23-38.

Baltaci, A. ve Coşkun, M. K. (2019). 2023 Eğitim Vizyon Belgesine ilişkin öğretmen alg1si. HAYEF: Journal of Education, 16, 130-155.

Barton, L. and Walker, S. (2017). Education and social change. New York: Routledge.

Bayburtlu, Y . (2020). Okul dışı öğrenme ortamlarının Türkçe dersi ünitelendirilmiş yıllık planlarına yansımaları. İnsan ve Toplum Bilimleri Araştırmaları Dergisi, 9(5), 3835-3852.

Becerikli, S. Y. (2013). Türkiye'de sağlık iletişimi üzerine yazılan lisansüstü tezlerin bibliyometrik analizi: Eleştirel bir bakış. Ankara Sağ lık Hizmetleri Dergisi, 12(2), 25-36.

Bitirim Okmeydan, S. (2020). Kültürlerarası iletişim alanındaki eğilimler: Kültürlerarası İletişim başlıklı lisansüstü tezlerin bibliyometrik analizi. TRT Akademi, 5(10), 578-611.

Boyraz, M. ve Sandıkçı, M. (2018). Gastronomi bildirilerinin değerlendirilmesi: Turizm kongreleri örneği 2013-2017. Journal of Tourism and Gastronomy Studies, 6(4), 873-889. 
Bozdemir, E. ve Çivi, F. (2019). Standart maliyet yönteminin görsel haritalama tekniğine göre bibliyometrik analizi. Muhasebe ve Finansman Dergisi, 81, 59-84.

Bozdogan, A. E. (2020). Web of science veri tabanına dayalı bibliyometrik analiz: Bilim merkezleri/müzeleri üzerine yapılan eğitim araştırmaları makaleleri. Akdeniz Eğitim Araştırmaları Dergisi, 14(31), 174-194.

Can, E. (2019, Mayıs 2-4). 2023 Eğitim Vizyonu Belgesi: Öğretmenlik mesleğinde gelişim ihtiyact. 14. Uluslararası Eğitim Yönetimi Kongresi, Çeşme, İzmir, Türkiye. 478-482.

Canbal, M., Kerkez, B., Suna, E., Numanoğlu, K. ve Özer, M. (2020). Mesleki ve teknik ortaöğretimde paradigma değişimi için yeni bir adım: Eğitim programlarının güncellenmesi . Eğitim ve İnsani Bilimler Dergisi: Teori ve Uygulama, 11(21), 1-26.

Canbulat, M., Direkci, B., Simsek, E. E. ve Simsek, B. (2020b). Investigating the school 2023 project through the lens of teachers: A case study. Eurasian Journal of Educational Research, 89, 137-158.

Canbulat, M., Dïrekçi, B., Akbulut, S., Çorapçigil, A., Tezci, İ., Şïmşek, E., Şïsşek, B. ve ASMA, B. (2020a). Okul müdürlerinin gözünden "Okul 2023" projesinin incelenmesi. Abant İzzet Baysal Üniversitesi Eğitim Fakültesi Dergisi, 20(1), 570-584.

Cengiz, E. (2019). Millî Eğitim Bakanlığı tarafından uygulanan aday öğretmen yetiştirme sürecine ilişkin yapılan çalışmaların analizi. Eskişehir Osmangazi Üniversitesi Sosyal Bilimler Dergisi, 20(Özel Sayı), 829-849.

Chao, C. C., Yang, J. M. and Jen, W. Y. (2007). Determining technology trends and forecasts of RFID by a historical review and bibliometric analysis from 1991 to 2005. Technovation, 27(5), 268-279.

Coşkun İ., Dündar Ş. ve Parlak C. (2014). Türkiye'de özel eğitim alanında yapılmış lisansüstü tezlerin çeşitli değişkenler açısından incelenmesi (2008-2013). Ege Eğitim Dergisi. 15(2), 375-396.

Çağlayan E. ve Kıratlı, A. DİLEK (2017). Resim bölümlerinde uygulanan eğitim programları hakkında öğretim elemanı görüşleri. Hacettepe Üniversitesi Ĕ̆itim Fakültesi Dergisi, 32(4), 780-793.

Çarıkçı, O. ve Yaman, B. (2019). Muhasebe-finans öğrencileri üzerine yapılan araştırmaların bibliyometrik analizi. Kafkas Üniversitesi Iktisadi ve İdari Bilimler Fakültesi Dergisi, 10(19), 359-381. 
Çiçek, D. ve Kozak, N. (2012). Anatolia: Turizm Araştırmaları Dergisi'nde yayımlanan hakem denetimli makalelerin bibliyometrik profili. Türk Kütüphaneciliği, 26(4), 734-756.

Çil, O., Kuzu, O. ve Şïmşek, A. (2019). 2018 ortaöğretim matematik programınin revize bloom taksonomisine ve programın ögelerine göre incelenmesi. Yüzüncü Yal Üniversitesi Eğitim Fakültesi Dergisi, 16(1), 1402-1418.

Dayioğlu Öcal, S. ve İşcan, S. (2020). Millî Eğitim Bakanlığ1 2023 Eğitim Vizyonu Belgesi ve Dewey'nin Türkiye Maarifi hakkında raporu: Belge analizi. Anemon Muş Alparslan Üniversitesi Sosyal Bilimler Dergisi, 8(5), 1505-1518.

DergiPark

Dergipark

hakkinda.

https://dergipark.org.tr/tr/pub/page/about Erişim Tarihi: 18.03.2021

Dinçer, Ö. (1998). Stratejik yönetim ve işletme politikası. 5. Baskı. İstanbul: Beta Yayınları.

Doğan, M. C., Karakoç, Ç. ve Uysal, H. (2019, Ekim 23-27). Türk milli eğitim sisteminde 2023 Vizyonu ve eğitimde sosyal adalet. 2. Uluslararası Temel Eğitim Kongresi, Muğla, Türkiye.

Doğan, S. (2019). 2023 Eğitim Vizyonu Belgesine ilişkin okul yöneticileri ve öğretmen görüşleri. Cumhuriyet Uluslararası Eğitim Dergisi, 8(2), 571592.

Doğru, M., Gençosman, T., Ataalkin, A. ve Şeker, F. (2012). Fen bilimleri eğitiminde çalışılan yüksek lisans ve doktora tezlerinin analizi. Türk Fen Eğitimi Dergisi, 9(1), 49-64.

Duran, E. ve Kurt, M. (2019). 2023 eğitim vizyonuna ilişkin öğretmen görüşleri. Uluslararası Sosyal Bilgilerde Yeni Yaklaşımlar Dergisi, 3(1), 90-106.

Eğitim Reformu Girişimi (2018). Vizyon belgesi neler getiriyor ve nasıl güçlendirilebilir? https://www.egitimreformugirisimi.org/vizyonbelgesi-neler-getiriyor-ve-nasil-guclendirilebilir Erişim Tarihi: 18.03.2021

Emin, M. N. (2018). Eğitimde yeni yol haritası: 2023 Eğitim Vizyon Belgesi. https://www.setav.org/egitimde-yeni-yol-haritasi-2023-egitimvizyon-belgesi/ Erişim Tarihi: 18.03.2021

Erdoğan, M., Güzle Kayır, Ç., Kaplan, H., Aşık Ünal, Ü.Ö. ve Akbunar, Ş. (2015). 2005 yılı ve sonrasında geliştirilen öğretim programları ile il- 
gili öğretmen görüşleri; 2005-2011 yılları arasında yapılan araştırmaların içerik analizi. Kastamonu Ĕ̆itim Dergisi, 23(1), 171-196.

Ertürk, A. (2020). 2023 Eğitim Vizyonu: Sorunlara çare mi? Pamukkale Üniversitesi Ĕ̆itim Fakültesi Dergisi, 48, 321-345.

Gaur, S. S., Herjanto, H. and Makkar, M. (2014). Review of emotions research in marketing, 2002-2013. Journal of Retailing and Consumer Services, 21(6), 917-923.

Gelir, İ. (2019). The role of community-based early childhood programmes in children learning: The concept of funds of knowledge. International Journal of Educational Research Review,4(2),116-120.

Gökçen, D., ve Arslan, M. (2019). Türkçe eğitimi araştırmalarına genel bir bakış: Bibliyometri çalışması. Journal of Research in Turkic Languages, 1(1), 39-56.

Göktaş, Y., Küçük, S., Aydemir, M., Telli, E., Arpacık, Ö., Yıldırım, G. ve Reisoğlu, İ. (2012). Türkiye'de eğitim teknolojileri araştırmalarındaki eğilimler: 2000-2009 Dönemi Makalelerinin İçerik Analizi. Kuram ve Uygulamada Ĕ̆itim Bilimleri, 12(1), 177-199.

Gül, Ş. ve Sözbilir, M. (2015). Biology education research trends in Turkey. Eurasia Journal of Mathematics, Science ve Technology Education, 11(1), 93-109.

Günday, R. ve Cirit, H. (2019). Ortaöğretim özel program ve proje uygulayan eğitim kurumları'nın arka planı ve proje okul uygulamaları. Uluslararası Türk Kültür Coğrafyasında Sosyal Bilimler Dergisi, 4(2), 144-151.

Gündüz, G. (2020). Opinions of primary school teachers in relation to effectiveness and applicability of design skill workshops. Turkish Online Journal of Qualitative Inquiry, 11(4), 533-570.

Güner Yıldız, N., Melekoğlu M. A. ve Tunç Paftalı, A. (2016). Türkiye'de özel eğitim araştırmalarının incelenmesi. Ilköğretim Online, 15(4), 1076-1089.

Hamarat, E. ve Arkan, A. (2018). 2023 Eğitim Vizyon Belgesi'nde gelecek becerileri. Seta Perpektif, 222.

Hamarat, E. (2019). 21. Yüzyıl becerileri odağında Türkiye'nin eğitim politikaları. Seta Perspektif, 272. https://www.researchgate.net/publication/332267844 21 Yuzyil Bec erileri Odaginda Turkiye\%27nin Egitim Politikalari Erişim Tarihi: 18.03.2021 
Kanlı, U., Gülçiçek, Ç., Göksu, V., Önder, N., Oktay, Ö., Eraslan, F., Eryılmaz, A. V. ve Güneş, B. (2014). Ulusal fen bilimleri ve matematik eğitimi kongrelerindeki fizik eğitimi çalışmalarının içerik analizi. Gazi Üniversitesi Gazi Eğitim Fakültesi Dergisi, 34(2), 127-153.

Karadağ, E. (2009). Eğitim bilimleri alanında yapılmış doktora tezlerinin tematik açıdan incelemesi. Ahi Evran Üniversitesi Eğitim Fakültesi Dergisi, 10(3), 75-87.

Karagöz, B. ve Koç Ardiç, İ. (2019). Ana dili eğitimi dergisinde yayımlanan makalelerin bibliyometrik analizi. Ana Dili Eğitimi Dergisi, 7(2), 419435.

Karagöz, B. ve Şeref, İ. (2019a). Okuma alanındaki araştırmaların bibliyometrik özellikler açısından incelenmesi. Ana Dili Eğitimi Dergisi, 7(3), 781-799.

Karagöz, B. ve Şeref, İ. (2019b). Değerler Eğitimi Dergisi'nin bibliyometrik profili (2009-2018). Değerler Ĕ̆itimi Dergisi, 17(37), 219-246.

Karasar, N. (2017). Bilimsel Araştırma Yöntemi kavramlar ilkeler teknikler. Nobel.

KartaL, M. T. (2018). Türkiye'de faizsiz bankacilık alanında yayınlanmış tezlerin analizi. Maliye ve Finans Yazıları Dergisi, 110, 175-198.

Kaygalak Çelebi S. ve Kırlar Can B. (2019). Turizm rehberliği alaninda yapilan makalelerin bibliyometrik analizi. International Journal of Contemporary Tourism Research, 3(2), 213-223.

Kiral, B. ve Çilek, A. (2020). 2023 Vizyon Belgesi'nin karakter eğitimi bakımından değerlendirilmesi. Milli Eğitim Dergisi, 49(225), 5-22.

Koley, S. and Sen, B. K. (2016). Biobibliometric study of professor A. S. paintal, a celebrated medical physiologist, Library Herald, 54(2), 174190.

Koppl R. (2007). Entrepreneurial Behavior as a Human Universal. M. Minniti içinde, Entrepreneurship: The Engine of Growth, People. Londra: Praeger.

Kozak, N. (1994). Anatolia Dergisi'nde yayınlanan yazılar üzerine bir inceleme. Anatolia Turizm Araştırmaları Dergisi, 5(3), 22-33.

Köç, A. ve Ünal, O. (2018). Sosyal Bilgiler öğretmenlerinin 2023 Eğitim Vizyonuna yönelik görüşlerinin incelenmesi. Journal of Innovative Research in Social Studies, 1(2), 65-79.

Köksal, H . (2019). 2023 Eğitim Vizyon Belgesi, tekillik ve transhümanizm. Eğitim ve Toplum Araştırmaları Dergisi, 6(1), 145-157. 
Köseoğlu, M. A. (2016). Mapping the institutional collaboration network of strategic management research: 1980-2014. Scientometrics, 109(1), 203-226.

Kudak, H. ve Akın, E. (2020). 2023 Eğitim Vizyon Belgesiyle oluşturulan drama ve eleştirel düşünce atölyelerinin Türkçe dersi akademik başarısı üzerine etkisi . Avrasya Sosyal ve Ekonomi Araştırmaları Dergisi, 7(6), 58-74.

Lv, P. H., Wang, G. F., Wan, Y., Liu, J., Liu, Q. and Ma, F. C. (2011). Bibliometric trend analysis on global graphene research. Scientometrics, 88(2), 399-419.

MEB, (2018). T. C. Millı̂ Eğitim Bakanlığı 2023 Eğitim Vizyonu Belgesi. https://2023vizyonu.meb.gov.tr/ Erişim Tarihi: 21.03.2021

Miles, M.B., Huberman, A.M. and Saldana, J. (2014) Qualitative data analysis: A Methods Sourcebook. Sage, London.

Minaz, M. B. ve Dikmen, H. (2019). 2023 Vizyon Belgesi ile ilgili olarak okul yöneticilerinin görüşleri. Turkish Studies, 14(3), 699-722.

Murathan, G., Bozyılan, E. ve Murathan F. (2020). Fiziksel aktivite konulu Bibliyometrik analizi. Beden Eğitimi ve Spor Bilimleri Dergisi, 14(2), 158-167.

Muslu, Ş. (2014). Örgütlerde misyon ve vizyon kavramlarının önemi. Emek ve Toplum, 3(5), 150-171.

Neyişşi, N., Turabık, T., Gün, F. ve Kısa, N. (2020). Öğretmen adaylarının perspektifinden Türk Eğitim Sisteminin sorunları ve olası çözüm önerileri. Kastamonu Ĕ̆itim Dergisi, 28(6) , 2257-2270.

Özer, M. ve Perc, M. (2020). Dreams and realities of school tracking and vocational education. Palgrave Communications, 6(34), 1-7.

Örsdemir, F. ve İhtiyaroğlu, N. (2020). Nurettin Topçu ile Türk Eğitim Sistemini yeniden düşünmek. Çukurova Üniversitesi Eğitim Bilileri Fakültesi Dergisi, 49, 98-141.

Özer, M . (2020C). Educational policy actions by the ministry of national education in the times of COVID-19 Pandemic in Turkey. Kastamonu Eğitim Dergisi, 28(3), 1124-1129.

Özer, M. ve Eren, H. S. (2020). Covid-19 salgını ve eğitim. (Ed. Muzaffer Şeker, Ali Özer, Cem Korkut) Küresel salginın anatomisi: Insan ve toplumun geleceği (s.170-192). 
Özer, M. ve Suna, H. (2019). Future of vocational and technical education in Turkey: Solid steps taken after education vision 2023. Ĕ̆itim ve İnsani Bilimler Dergisi: Teori ve Uygulama, 10(20), 166-192.

Özer, M. ve Suna, H. (2020). Covid-19 Salgını ve eğitim. M. Şeker, A. Özer ve C. Korkut (Ed.) Küresel Salginın Anatomisi, (s.173-192). Şehir: Yayın evi

Özer, M. (2018). 2023 Eğitim Vizyonu ve mesleki ve teknik eğitimde yeni hedefler. Yüksek Öğretim ve Bilim Dergisi, 8(3), 425-435.

Özer, M. (2019a). Background of problems in vocational education and training and its road map to solution in Turkey's Education Vision 2023. Journal of Higher Education and Science, 9(1), 1-11.

Özer, M. (2019b). Reconsidering the fundamental problems of vocational education and training in Turkey and proposed solutions for restructuring. İstanbul Üniversitesi Sosyoloji Dergisi, 39(2), 1-19.

Özer, M. (2020a). Türkiye'de mesleki eğitimde paradigma değişimi . Gazi Üniversitesi Gazi Ĕ̆itim Fakültesi Dergisi, 40(2) , 357-384.

Özer, M. (2020b). The contribution of the strengthened capacity of vocational education and training system in Turkey to the fight against Covid19. Yükseköğretim Dergisi, 10(2), 134-140.

Özer, M. (2020d). Vocational education and training as "a friend in need" during coronavirus pandemic in Turkey. Bartm University Journal of Faculty of Education, 9(2), 1-7.

Özer, M. (2021). Türkiye'de okullar arası başarı farklarını azaltmaya yönelik yeni bir adım: "Mesleki ve Teknik Eğitimde 1.000 Okul" projesi. Bartin University Journal of Faculty of Education, 10(1), 97-108.

Özer, M., Çavuşoğlu, A., Gür, B. S. (2011). Restorasyon ve toparlanma dönemi: Mesleki ve teknik eğitimde 2000'li yıllar. B. S. Gür (Ed.) 2000'li Yillar: Türkiye'de Eğitim (s.163-192). İstanbul: Meydan.

Özkan, U. B. (2019). Eğitim bilimleri araştırmaları için doküman inceleme yöntemi. Pegem Akademi.

Öztürk, Z. (2020). Tasarım ve beceri atölyelerine yönelik uygulamalar - Almanya örneği. Milli Ĕ̆itim Dergisi, 49(227), 141-158.

Perc, M., Özer, M. and Hojnik, J. (2019). Social and juristic challenges of artificial intelligence. Palgrave Communications, 5(10), 1-8.

Polat Üzümcü, T. (2019). Turizm eğitimi alanına yönelik bibliyometrik bir çalışma. Türk Turizm Araştırmaları Dergisi, 3(4), 1433-1449. 
Saban, A. (2009). Çoklu zekâ kuramı ile ilgili Türkçe çalışmaların içerik analizi. Kuram ve Uygulamada Eğitim Bilimleri, 9(2), 833-876.

Saban, A., Koçbeker Eid, B. N., Saban, A., Alan, S., Doğru, S., Ege, İ., Arslantaş, S., Çınar, D. ve Tunç, P. (2010). Eğitim bilim alanında nitel araştırma metodolojisi ile gerçekleştirilen makalelerin analiz edilmesi. Selçuk Üniversitesi Ahmet Keleşoğlu Eğitim Fakültesi Dergisi, 30, 125142.

Sayğan Tunçay, S. ve Sürgevil Dalkılıç, O. (2017). Yönetim ve organizasyon bilim alanında ortak yazarlılık. Journal of Business Research-Türk, 9(3), 393-423.

Selçuk, Z., PalancI, M., Kandemir., M. ve Dündar., H. (2014). Eğitim ve bilim dergisinde yayınlanan araştırmaların eğilimleri: İçerik analizi. Ĕ̆gitim ve Bilim, 39(173), 430-453.

Semerci, Ç., Hatipoğlu, C., Güneri, B., Sevimbay, A., Akcaalan, M. ve Cengiz Demir, Y. (2020). The future of education in Turkey's 2023 Educational Vision Document: Views of academicians in the faculty of education. Eurasian Journal of Educational Research, 87, 69-100.

Solak, Y. ve Karataş, S. (2020). 2023 Eğitim Vizyonu hakkında eğitim yöneticileri görüşleri. Akdeniz Üniversitesi Ĕ̆itim Fakültesi Dergisi, 3(2), 1-18.

Sökmen, C. ve Özkanlı, O. (2018) Gastronomi turizmi alanyazının gelişimi: Journal of tourism and gastronomy studies dergisinde yayımlanan makaleler üzerine bir inceleme. Journal of Tourism and Gastronomy Studies, 6(2), 99-127.

Sözer, M. A. (2019). 2023 Vizyon Belgesinde temel eğitim. Seta Perpektif, 227. https://setav.org/assets/uploads/2019/01/P227.pdf Erişim Tarihi: 18.03.2021

Springer (2021). Title, Abstract and Keywords. https://www.springer.com/gp/authorseditors/authorandreviewertutorials/howtopeerreview/title-abstractand-key-words/10286400 Erişim Tarihi: 19.03.2021

Sünnetçioğlu, A., Yalçınkaya, P., Olcay, M., ve Okan, Ş. (2017). Turizm alanında yazılmış olan gastronomiye ilişkin tezlerin bibliyometrik profili. Journal of Tourism and Gastronomy Studies, 5(Special Issue 2), 345354.

Şad, S. ve Sarı, M. (2019). İngilizce öğretmenlerinin erken yaşta İngilizce öğretimine ilişkin yeterlilik düzeyleri (Kütahya ili örneği). Inönü Üniversitesi Ĕ̆itim Bilimleri Enstitüsü Dergisi, 6(12), 144-163. 
Şeref, İ. ve Karagöz, B. (2019). Scopus veri tabanına dayalı bibliyometrik değerlendirme: Mevlâna Celâleddin Rumî üzerine yapılan araştırmalar. Rumelide Dil ve Edebiyat Araştırmaları Dergisi, 14, 298-313.

Tang, M., Liao, H. and Su, S. F. (2018). A bibliometric overview and visualization of the International journal of fuzzy systems between 2007 and 2017. International Journal of Fuzzy Systems, 20(5), 1403-1422.

Tarhan, M. (2019). MEB 2023 Eğitim Vizyonu çerçevesince Türkiye'de girişimcilik eğitiminin geleceğine yönelik bir değerlendirme. Abant İzzet Baysal Üniversitesi Ĕ̆itim Fakültesi Dergisi, 19(2), 667-682.

Taş, H. ve Kıroğlu, K. (2017). Assessment of the 2017 primary school social studies curriculum according to teachers' views. Elementary Education Online, 17(2), 697-716

Taş, H. (2018). 2023 Eğitim vizyonunun teftiş ve kurumsal rehberlik düzenlemesi üzerine bir değerlendirme. Ĕ̆itime Bakış, 44, 10-17.

Tayfun, A., Ülker, M., Gökçe, Y., Tengilimoğlu, Sürücü, Ç. ve Durmaz, M. (2018); Turizm alanında yiyecek ve içecek ile ilgili lisansüstü tezlerin bibliyometrik analizi. Journal of Tourism and Gastronomy Studies, 6(2), 503-527.

TDK, (2020). Türk Dil Kurumu. https://sozluk.gov.tr/ Erişim Tarihi: 21.03.2021

Tekin, B. (2019). Davranışsal kurumsal finans alanında yapılan çalışmaların bibliyometrik analizi. SETSCI Conference Proceedings, 4(8), 31-35.

Temizkan, S. P., Çiçek, D. ve Özdemir, C. (2015). Sağllk turizmi konusunda yayınlanan makalelelerin bibliyometrik profili. International Journal of Human Sciences, 12(2),394-415.

Türk Eğitim-Sen. (2018). Türk Eğitim Sistemine ilişkin görüş ve öneriler. Türk Ĕ̆itim-Sen Raporu.

Varişoğlu, B., Şahin, A. ve Göktaş, Y. (2013). Türkçe eğitimi araştırmalarında eğilimler. Kuram ve Uygulamada Eğitim Bilimleri, 13(3), 1767-178.

Wang, W. M. and Ho, Y. S. (2017). Bibliometric analysis of art exhibit reviews in the Arts ve Humanities Citation Index. Malaysian Journal of Library ve Information Science, 22(1), 59-68.

Yalçın, H. (2010). Millî folklor dergisinin bibliyometrik profili (2007-2009). Millî Folklor, 22(85), 205-211.

Yatmaz, A. (2019). 2023 Eğitim Vizyonu'nda okulların finansmanı. Seta Perspektif, 231. 
Yeksan, Ö. ve Akbaba, A. (2019). Sürdürülebilir turizm makalelerinin bibliyometrik analizi. Güncel Turizm Araştırmaları Dergisi, 3(2), 220-231.

Yildirim, A. ve Şimşek, H. (2018). Sosyal bilimlerde nitel araştırma yöntemleri. Ankara: Seçkin.

Yılmaz, G. (2017). Restoranlarda bahşiş ile ilgili yayınlanan makalelerin bibliyometrik analizi. Seyahat ve Otel İşletmeciliği Dergisi, 14(2), 65-79.

Yurtsever, E. (2018). Bilimsel yayınlar nasıl değerlendirilmeli? San Francisco bildirisi. $\quad$ https://sarkac.org/2018/09/bilimsel-yayinlar-nasildegerlendirilmeli/ Erişim Tarihi: 20.03.2021

Zan, B. U. (2013). ULAKBİM sosyal ve beşerî bilimler veri tabanında indekslenen Çankırı Karatekin Üniversitesi yayınların analizi. Çankırı Karatekin Üniversitesi Sosyal Bilimler Enstitüsü Dergisi, 4(2), 227-238.

Zencir, E. ve Kozak, N. (2012). Sosyal bilimler enstitü dergilerinde yayınlanan turizm makalelerinin bibliyometrik profili (2000-2010). VI. Lisansüstü Turizm Öğrencileri Araştırma Kongresi, 12-15 Nisan 2012, 673-682.

Zhao, L., Deng, J., Sun, P., Liu, J., Ji, Y., Nakada, N., Qiao, Z., Tanaka, H. and Yang, Y., (2018). Nanomaterials for treating emerging contaminants in water by adsorption and photocatalysis: systematic review and bibliometric analysis. Science of the Total Environment, 627, 1253-1263.

\section{Kaynakça Bilgisi / Citation Information}

Ayanoğlu, Ç., Demir, T. ve Gür Erdoğan, D. (2021). 2023 Eğitim Vizyonunun akademik çalışmalara yansımaları: Bibliyometrik bir analiz. OPUS-Uluslararası Toplum Araştırmaları Dergisi, 18(Eğitim Bilimleri Özel Sayıs1), 4482-4518. DOI:10.26466/opus.918815. 